\title{
Preliminary Report on Methodology for Calculating Coal Resources of the Wyodak-Anderson Coal Zone, Powder River Basin, Wyoming and Montana
}

By

Margaret S. Ellis, Gregory L. Gunther ${ }^{1}$, Romeo M. Flores, Gary D. Stricker, Allan M. Ochs ${ }^{1}$, and John H. Schuenemeyer

Online Edition

This report has not been reviewed for conformity with U.S. Geological Survey editorial standards and stratigraphic nomenclature. Any use of trade names is for descriptive purposes only and does not imply endorsement by the U.S. Government.

${ }^{1}$ Contractor for the U.S. Geological Survey, Denver, Colorado 


\section{Table of Contents}

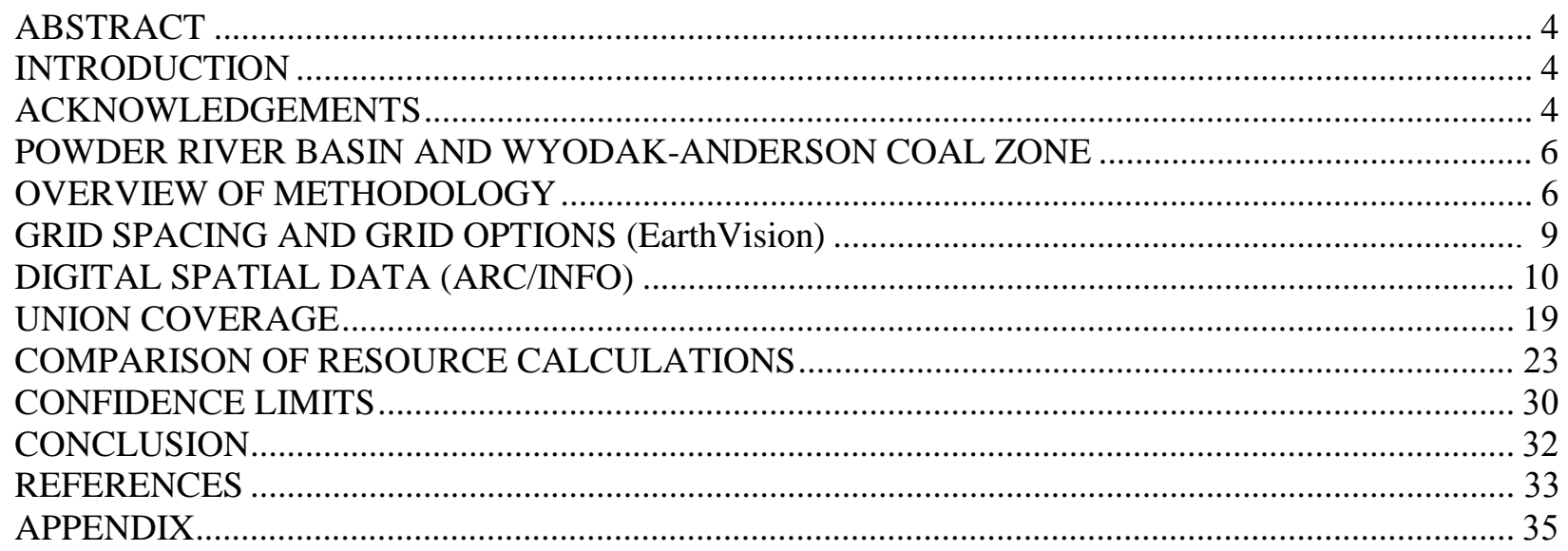

FIGURES

Figure 1.

Figure 2.

Figure 3.

Figure 4.

Figure 5.

Figure 6.

Figure 7.

Figure 8.

Figure 9.

Figure 10.

Figure 11.

Figure 12. Figure 13.

TABLES

Table 1.

Table 2.

Table 3.
Index map of the Northern Rocky Mountain and Great Plains Region.............................. 5

Production of all coal in Wyoming, Montana, and North Dakota from 1960 to 1997 ....... 7

Generalized cross-section showing the type of lateral and horizontal variation found in

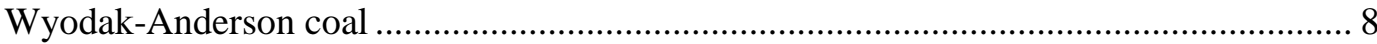

Isopach maps of net coal in the Wyodak-Anderson coal zone showing the difference between isolines created using the 3,520 by 3,606-m EarthVision default grid spacing and the 300 by $300-\mathrm{m}$ grid spacing....

Isopach maps of net coal in the Wyodak-Anderson coal zone showing the differences between isolines created using the isopach grid option verses the normal minimum tension grid option

Maps showing the Montana/Wyoming state boundary, counties, the Powder River Basin boundary, tribal lands, and Wyodak-Anderson coal zone clinker, mines, and lease

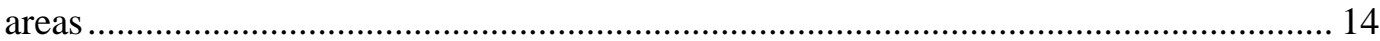

Map showing the location of 7.5-minute quadrangle maps in the study area................... 15 Map showing coal resource reliability categories in the Wyodak-Anderson study area... 17 Map showing Federal ownership categories in the Powder River Basin ........................... 18 Shaded relief map of the Powder River Basin and vicinity showing topography generated from the DEM (Digital Elevation Model)......................................................... 20

Map of the Wyodak-Anderson study limit in the Powder River Basin showing

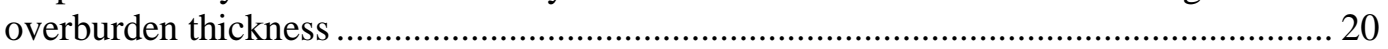

Net coal isopach map of the Wyodak-Anderson coal zone ........................................... 21 Map showing union coverage polygons used for the study of the Wyodak-Anderson coal zone in a portion of the study area.

Comparison of EarthVision coal resource calculations of the Wyodak-Anderson coal zone using 300 by $300-\mathrm{m}$ isopach versus 300 by 300 -m normal minimum tension grid options, reported by state and county

Comparison of EarthVision coal resource calculations of the Wyodak-Anderson coal zone using net coal thickness grids with different grid spacings, reported by state and county

Comparison of average net coal thickness and total coal resources for the WyodakAnderson coal zone calculated using EarthVision versus ARC/INFO methods, reported by state and county 


\section{TABLES CONTINUED}

Table 4. Key to 7.5-minute quadrangle maps in the study area..

Table 5. Comparison of EarthVision coal resource calculations of the Wyodak-Anderson coal zone using 300 by $300-\mathrm{m}$ isopach versus 300 by $300-\mathrm{m}$ normal minimum tension grid options, reported by coal thickness categories.

Table 6. Comparison of coal resources for the Wyodak-Anderson coal zone calculated using EarthVision versus ARC/INFO methods, reported by coal thickness categories.............. 30

Table 7. Wyodak-Anderson confidence limits parameters and results........................................ 32 


\begin{abstract}
The National Coal Resource Assessment of the Wyodak-Anderson coal zone includes reports on the geology, stratigraphy, quality, and quantity of coal. The calculation of resources is only one aspect of the assessment. Without thorough documentation of the coal resource study and the methods used, the results of our study could be misinterpreted. The task of calculating coal resources included many steps, the use of several commercial software programs, and the incorporation of custom programs. The methods used for calculating coal resources for the Wyodak-Anderson coal zone vary slightly from the methods used in other study areas, and by other workers in the National Coal Resource Assessment.

The Wyodak-Anderson coal zone includes up to 10 coal beds in any given location. The net coal thickness of the zone at each data point location was calculated by summing the thickness of all of the coal beds that were greater than $2.5 \mathrm{ft}$ thick. The amount of interburden is not addressed or reported in this coal resource assessment. The amount of overburden reported is the amount of rock above the stratigraphically highest coal bed in the zone. The resource numbers reported do not include coal within mine or lease areas, in areas containing mapped Wyodak-Anderson clinker, or in areas where the coal is extrapolated to be less than $2.5 \mathrm{ft}$ thick.

The resources of the Wyodak-Anderson coal zone are reported in Ellis and others (1998). A general description of how the resources were calculated is included in that report. The purpose of this report is to document in more detail some of the parameters and methods used, define our spatial data, compare resources calculated using different grid options and calculation methods, and explain the application of confidence limits to the resource calculation.
\end{abstract}

\title{
INTRODUCTION
}

The National Coal Resource Assessment is a project by the U.S. Geological Survey begun in 1995. It is an assessment of coal in the United States that has the highest potential for development within the next 20-30 years. For the purpose of the assessment, five study regions were identified within the United States. These regions are the Appalachian Basin, the Illinois Basin, the Gulf Coast, the Rocky Mountains and Colorado Plateau, and the Northern Rocky Mountains and Great Plains (figure 1). Within these regions, coal was prioritized and the coal beds and zones with the highest potential for development were designated as assessment units. Efforts were made to standardize the assessment of coal in all of the regions. The characteristics of the coal, stratigraphy, and available data, as well as the types and nature of the mine areas and technology employed in different areas is, however, unique; therefore the methodology employed for each study was modified as necessary.

Early in the National assessment it was determined that resources would be calculated using standard resource reporting categories from Wood and others (1983). The computer software used, data modeling options, and methods for calculating resources were to be determined by the workers in each study area. This report explains some of the options considered in determining the methods employed for Northern Rocky Mountains and Great Plains Region studies, with examples from the study of the Wyodak-Anderson coal zone in the Powder River Basin of Wyoming and Montana. Additional methods considered and employed in other regions in the National Coal Resource Assessment are reported in Tewalt (1998), Roberts and others (1998) and Roberts and Biewick (in press). Methods for calculating and reporting coal resources vary because of considerations resulting from different mining methods, restrictions, and geology in each study area, as well as the availability of software and the expertise of individual workers.

\section{ACKNOWLEDGEMENTS}

Many individuals and organizations contributed to this study. Much of the data for the study was obtained from the U.S. Geological Survey National Coal Resource Data System (NCRDS), the Office of Surface Mining, the Bureau of Land Management, the Wyoming Geological Survey, and the 


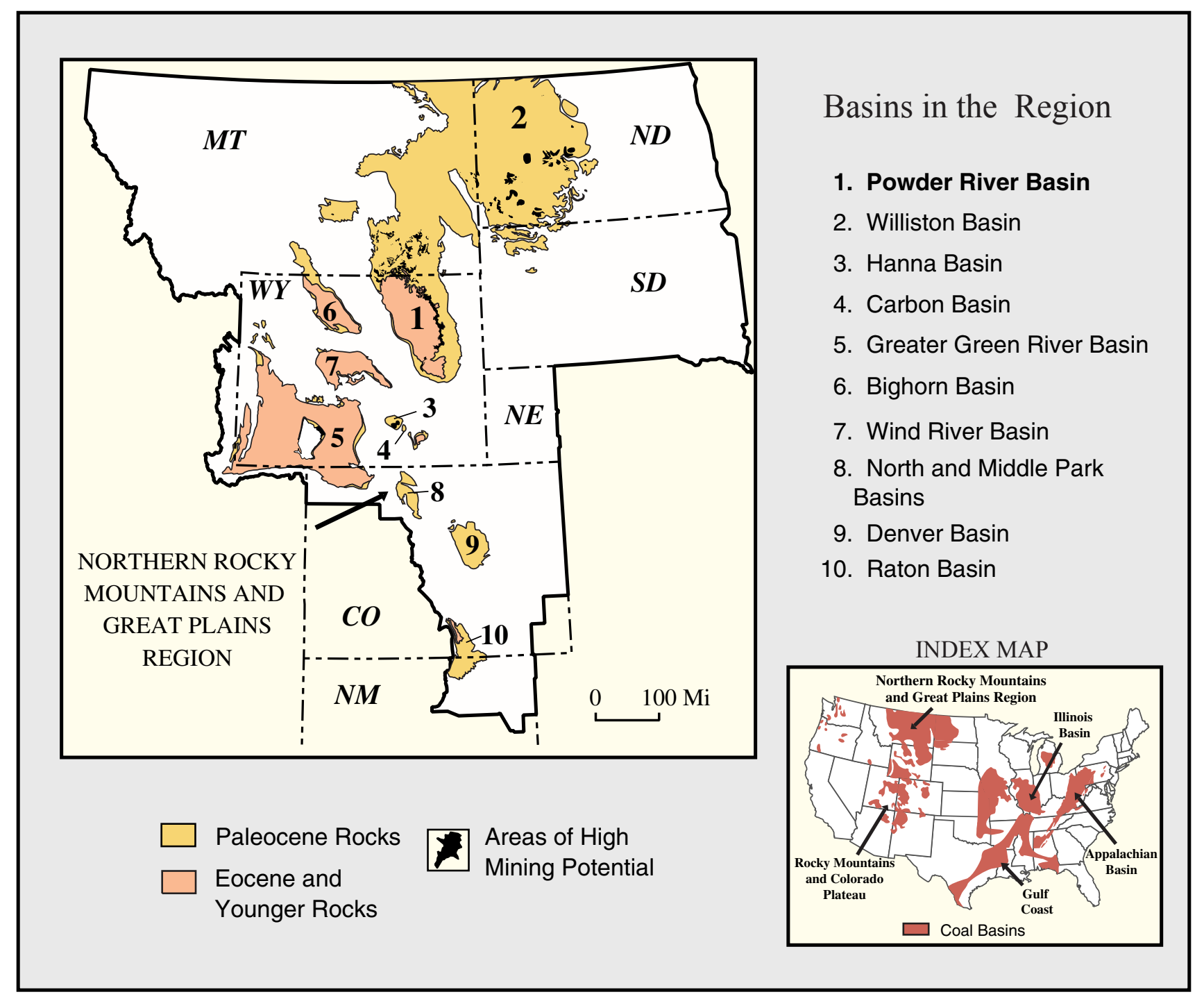

Figure 1. Index map of the Northern Rocky Mountains and Great Plains Region showing sedimentary basins, the outcrop of Paleocene, and Eocene and younger rocks, and areas of high mining potential. 
Montana Bureau of Mines and Geology. Some other agencies and companies supplied information for this study, however they cannot be acknowledged due to the proprietary status of the data.

Workers who supplied and correlated data for the Wyodak-Anderson coal zone include Daniel Vogler (Wyoming Geological Survey); Edith Wilde (Montana Bureau of Mines and Geology); and Peter Warwick, Ronald Johnson, Frances Wahl Pierce, and Carol Molnia (U.S. Geological Survey). Additional workers that entered data and produced digital coverages were Gerald Forney, Timothy Gognat, James Hunsicker, Gregory Rossi, Scott Kinney, Kathy Yates, Thomas Taber, Gregory Rossi, Scott Kinney, and Paul Hagen.

Several custom programs were used in various steps of the resource study. These programs were written and supplied by Colin Treworgy of the Illinois State Geological Survey (ismarc program) and by Dorsey Blake and Gary Stricker of the U.S. Geological Survey (evrpt and parting/split programs respectively).

\section{POWDER RIVER BASIN AND WYODAK-ANDERSON COAL}

The Powder River Basin is in the central part of the Northern Rocky Mountains and Great Plains Region, in Wyoming and Montana (figure 1). More than 30\% of the nation's 1996 total coal production of 1.06 billion short tons was produced from 14 Tertiary coal beds and zones in the Northern Rocky Mountains and Great Plains Region (Energy Information Agency, 1997). Coal that is being studied in this region is within the Powder River, Williston, Hanna, Carbon, and Greater Green River Basins. The greatest amount of coal production in the region is from mines in Wyoming, Montana, and North Dakota (figure 2). Coal production in Wyoming accounted for approximately $25 \%$ of total National coal production for 1997 (Energy Information Agency, 1998), with the highest coal production from the Wyoming part of the Powder River Basin, which is mainly Wyodak-Anderson coal.

For this study we are assessing the late Paleocene Wyodak, Anderson, and stratigraphically equivalent coal beds in the upper Fort Union Formation. The Fort Union Formation is exposed along the margin of the Powder River Basin, and is overlain by exposures of the Eocene Wasatch Formation, in the central part of the basin (figure 1). The Powder River Basin is an asymmetrical structural basin, with an axis trending northwest southeast along the western part of the basin. Fort Union rocks dip an average $20-25^{\circ}$ to the east along the western margin of the basin and have an average dip of $2-5^{\circ}$ to the west along the eastern margin of the basin. The Powder River Basin covers more than 12,000 square miles (31,080 square kilometers) and the Fort Union Formation is more than $6,000 \mathrm{ft}(1,830 \mathrm{~m})$ thick along the basin axis.

The upper part of the Fort Union Formation contains Wyodak-Anderson net coal that is more than $200 \mathrm{ft}(61 \mathrm{~m})$ thick. Beds included in the coal zone are the Anderson, Dietz, Canyon, Monarch, Werner, Wyodak, Smith, Swartz, Sussex, School, and Badger. The coal zone is more than $600 \mathrm{ft}$ (183 $\mathrm{m})$ thick, measured from the top of the uppermost coal to the base of the lowermost coal. The coal beds merge into a single coal bed as much as $202 \mathrm{ft}(62 \mathrm{~m})$ thick in the west-central part of the basin, and as much as $120 \mathrm{ft}(37 \mathrm{~m})$ thick in the eastern part of the basin. The coal beds are laterally discontinuous, and beds characteristically pinch-out, merge, and/or split within short distances. The lateral variability of the coal beds is shown in the cross section in figure 3.

Depositional setting controlled the thickness and lateral continuity of the Wyodak-Anderson coals. The depositional environments of the Fort Union Formation were mainly fluvial systems consisting of braided and meandering streams in the center of the basin and alluvial fans along the western basin margin. Coals accumulated in peat mires or swamps formed in fluvial floodplains, abandoned fluvial channels, and inter-channel environments (Flores, 1986).

\section{OVERVIEW OF METHODOLOGY}

The methods used in performing the coal resource calculations for the Wyodak-Anderson coal zone required many steps and a number of software packages and custom programs. A brief description of the steps involved, parameters selected, and software used for this study is given in Ellis and others (1998). 


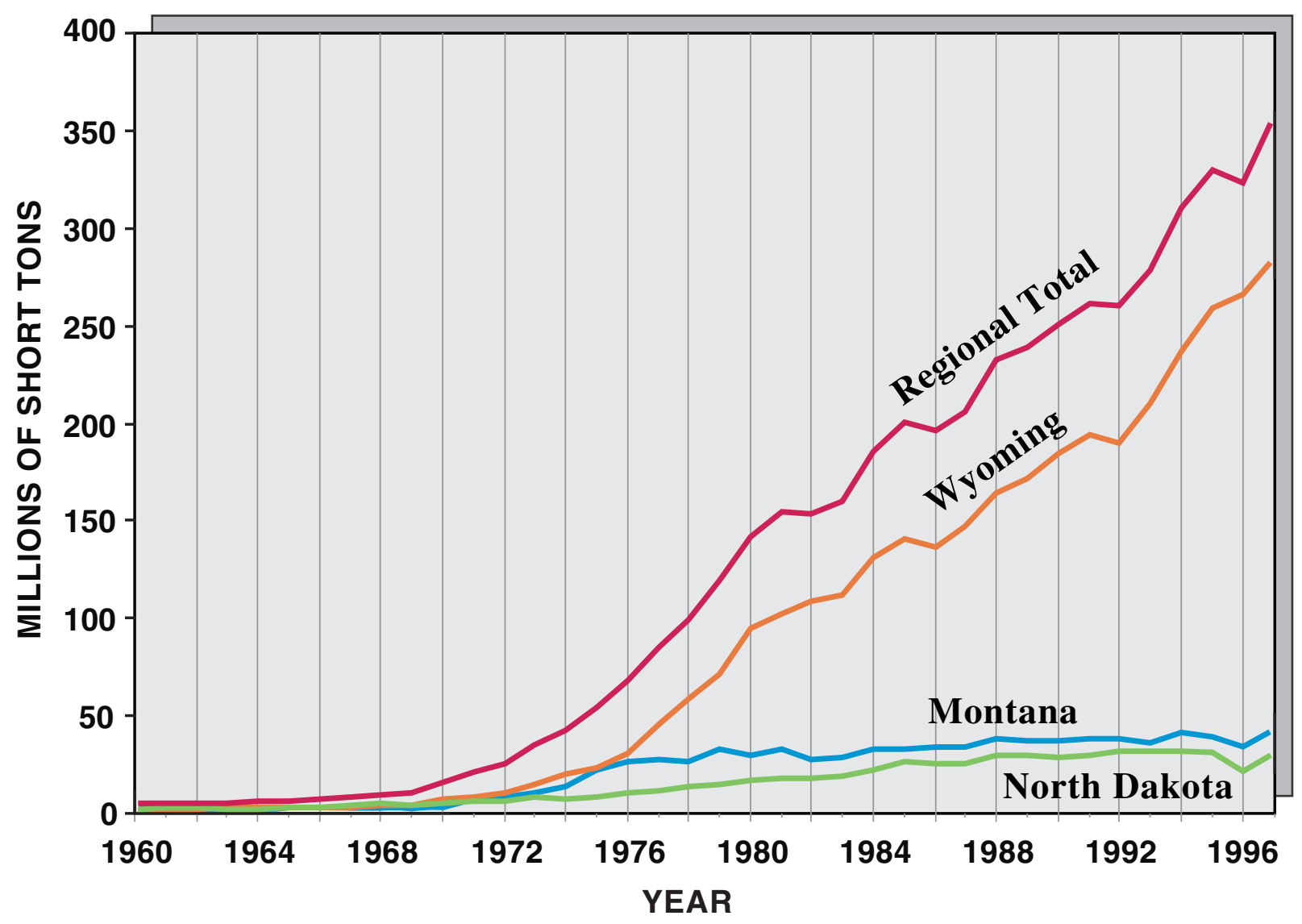

(Data from Energy Information Administration (EIA), 1998)

Figure 2. Production of all coal in Wyoming, Montana, and North Dakota from 1960 to 1997. 


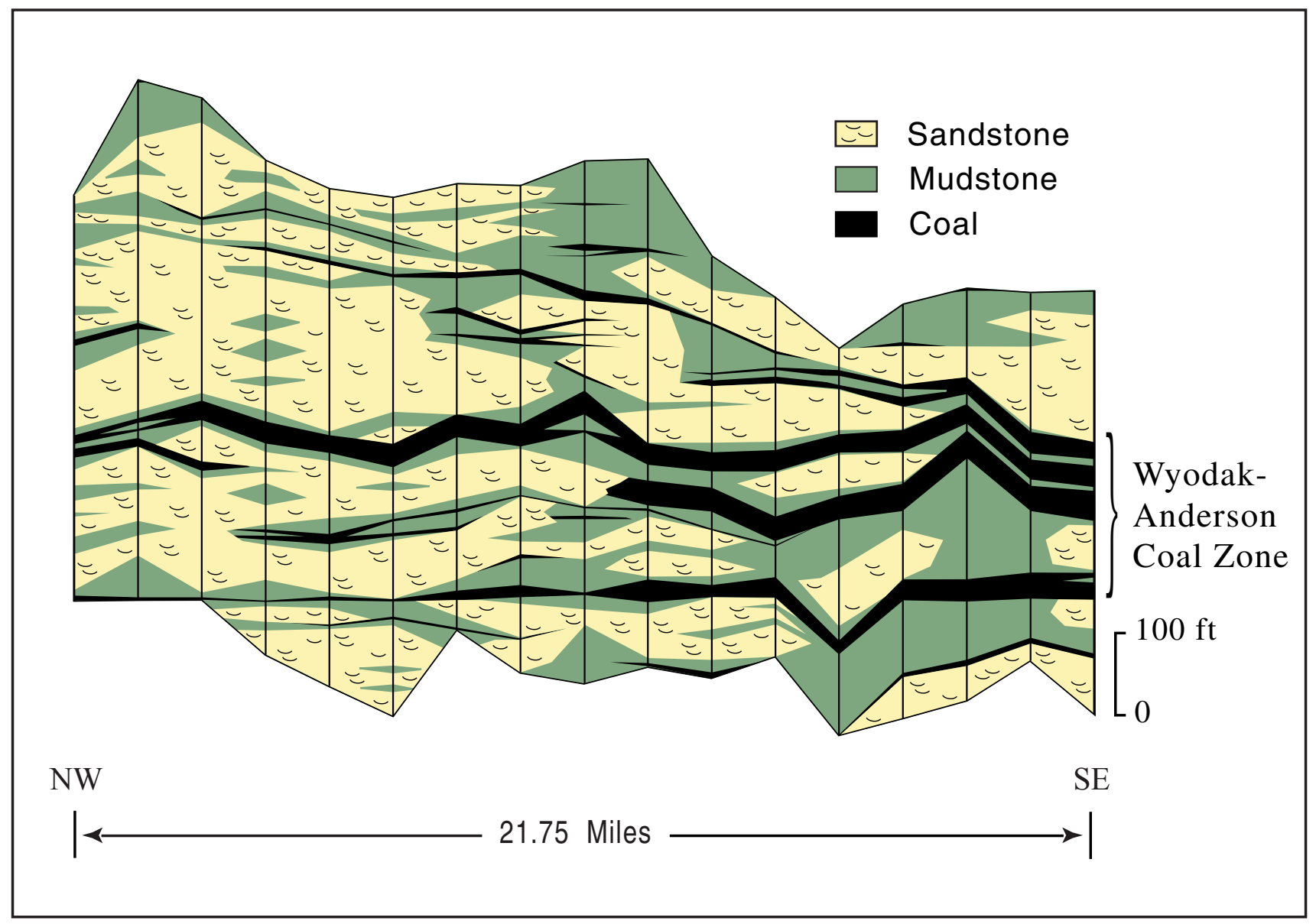

Figure 3. Generalized cross section showing the type of lateral and horizontal variation found in WyodakAnderson coal in the Powder River Basin of Wyoming and Montana. The cross section is located about three miles north of Gillette, Wyoming. 
The parameters and methods used for resource calculation could have a significant influence on the amount of resources calculated. As part of the Powder River Basin Wyodak-Anderson coal assessment we tested different methods to see what influence, if any, the methods would have on our calculations.

The methods that were used for the resource study involve the use of Stratifact (GRG Corp., 1996) as a relational database in which to compile all of our data and establish coal zone correlations, a USGS custom "parting/split" program to calculate net coal at each data point location, and EarthVision (Dynamic Graphics Inc., 1997) to create the net coal and overburden isopach maps. In EarthVision (EV), the grid spacing, grid options, and editing of the grid or the isopach lines affect the coal thickness used for resource calculations. The coal thickness and overburden isopach maps are imported into ARC/INFO (ESRI, 1998a) and combined with other spatial data layers. The combined spatial data (union coverage) contains polygons with many attributes. This coverage is used for eliminating specific areas from resource calculations and for reporting coal resources by categories.

Resources can be calculated in ARC/INFO, using the attribute of the net thickness and area of each polygon in the union coverage, or the union coverage can be imported into EarthVision and the resources can be calculated for each polygon using the net coal thickness grid. In this report both options were tested. The first option is referred to as the ARC/INFO method, and the second option is referred to as the EarthVision method. The following chapters describe options for gridding and calculating coal resources, and compare resource calculations resulting from the two different methods.

\section{GRID SPACING AND GRID OPTIONS (EarthVision)}

Data files were imported into EV in fixed ASCII format, with locations in decimal degrees of latitude and longitude. The data fields were defined and the file was projected to a standardized projection for the Wyodak-Anderson study area. The projection for the study area is Lambert Conformal Conic, Clarke 1886 spheroid, with a first standard parallel of 33 degrees, a second standard parallel of 45 degrees, a central meridian of 106 degrees west, an origin of 0 degrees, 0 false easting, and 0 false northing.

There are two grid options in EV, the isopach grid and the normal minimum tension (NMT) grid. The isopach grid option allows for special handling of thickness data that does not represent the entire coal zone (the drill holes did not penetrate the entire zone). In our data set there were 792 data points that fit this criteria, and were therefore considered to be "terminated". To indicate the points that were terminated, a negative sign was assigned to the coal thickness values in the data set. This negative coal thickness value is treated as a "greater than" value when using the isopach gridding.

The NMT gridding has special "0" handling, but does not compensate for terminated data. To test the isopach and NMT grid options, we therefore used two separate data sets. The data set used for the NMT grids did not contain data from terminated holes. This data set contained 4,622 data points with a $\mathrm{z}$ range of 0 to $284 \mathrm{ft}(0$ to $87 \mathrm{~m})$ thick. The data set used for isopach gridding contained data from terminated holes (negative values) and consisted of 5,414 data points with net coal values (z) that ranged from -169 to $284 \mathrm{ft}$ ( -52 to $87 \mathrm{~m})$ thick.

Data points were not evenly distributed throughout the study area; therefore, grids and isopach maps generated strictly from the original data did not accurately depict the character of the coal. It was necessary to add interpretive points to the data set based on geologic knowledge, field experience, and additional measured sections. These interpretive points included adding " 0 " values in areas along the coal extent where the coal was known to pinch-out (depositional "want" areas), or where the coal was eroded away (erosional "want" areas). The addition of interpretive data to the data sets allowed us to grid the data using several different grid spacings and both the isopach and NMT grid options without having to edit every isopach map.

When calculating grids, we found that it was best to grid first with a grid range from 0 to 285 to determine where the program placed 0 values. A second grid was then produced with a $\mathrm{z}$ range of 1 to 285 to avoid having the program interpolate or extrapolate the grid nodes to 0 values in areas where the data points were widely spaced. We used the second grid to calculate resources. When calculating resources in $\mathrm{EV}$, the values of the grid nodes are used for the coal thickness. There must be at least one 
grid node in a polygon for resources to be calculated in the polygon. Because many of the polygons in our union coverage were very small and therefore contained few grid nodes, by not gridding to 0 , we eliminated the possibility of calculating 0 short tons in the small polygons.

To choose the grid spacing and grid option (isopach vs. NMT) that was appropriate for our study, we considered the grid reports and the associated graphics (net coal isopach maps). Considerations used for choosing the appropriate grid were: a grid that honored (used) as many of the data points as possible and produced a small average absolute $\mathrm{z}$ error, as shown in the grid report; a grid that produced an isopach map with a reasonable level of detail; and a grid spacing that was small enough to allow at least one grid node value within each union coverage polygon. Because the size of the union polygons was a consideration, we created grids based on their spacing in meters (grid spacing) rather than the number of columns and rows in the grid (grid size).

The EV grid reports included in the Appendix of this report provide information on how the grids with different grid spacings represented the data. All of the grids were produced using the same grid range (a box defined just outside of the Wyodak-Anderson study limit) and 4 multiple data points (the number of closest surrounding data points that the grid algorithm uses in determining the value of each grid node.) We began by testing the default EV grid size of 81 by 123 (columns and rows) that equates to a grid spacing of 3,520 by $3,606 \mathrm{~m}$ (1,073 by 1,099 ft) (map A. on fig. 4). Grid spacings of 1,000 by $1,000 \mathrm{~m}, 800$ by $800 \mathrm{~m}, 500$ by $500 \mathrm{~m}$, and 300 by $300 \mathrm{~m}$ were tested. Grid ranges of both 0 to 285 and 1 to 285 were run, however only the grid reports for the $\mathrm{z}$ range of 1 to 285 are included in the Appendix. Highlighted areas in the grid reports indicate the number of data points in the data set, the number of data points used to produce the grid, and the average absolute $\mathrm{z}$ error of the grid. Isopach maps were generated using different grid spacings and using different grid options.

The results of our testing led to the selection of the 300 by $300-\mathrm{m}$ and 500 by $500-\mathrm{m}$ isopach grids as most representative of our study area. The 300 by $300-\mathrm{m}$ isopach and NMT grids both honored over $98 \%$ of the data points, using 5,324 out of 5,414 (98\%) data points for the isopach grid and 4,615 out of 4,622 (99.8\%) data points for the NMT grid. The average absolute grid error was $.5 \%$ for the isopach grid and $.4 \%$ for the NMT grid. The isopach and NMT grid isopach maps look very similar in their general configuration. Maps in figure 5 show isopach maps created using the isopach (A.) and NMT (B.) grid options with 300 by 300 -m grid spacing. Because isopach maps created using the two grid options were so similar and there were many terminated holes in our data set, we used the isopach grid option for the creation of the net coal coverage in ARC/INFO and for the calculation of volumetrics in EV. To determine what effect using the different grid options would have on the coal resources; we calculated volumetrics using the both the 300 by $300-\mathrm{m}$ isopach grid and the 300 by $300-\mathrm{m}$ NMT grid. The results are shown in table 1.

As an example of how grid spacing affects isolines on net coal isopach maps, figure 4 shows isopach maps created using the 3,520 by 3,606-m (EV default) grid spacing (map A.) and the 300 by 300-m grid spacing (map B.). The default grid spacing creates an isopach map that has very little detail. The difference between the isopach maps created using 500 by $500-\mathrm{m}$ and the 300 by $300-\mathrm{m}$ grid spacing is very slight. We decided to use the 500 by $500-\mathrm{m}$ isopach grid for creating the net coal isopach coverage in ARC/INFO because it had the same general configuration as the smaller spaced grid, yet it had fewer very small polygons that would be a problem in the union coverage.

\section{DIGITAL SPATIAL DATA (ARC/INFO)}

Layers of digital information were created and made into ARC/INFO coverages for use in various aspects of the resource assessment. The coverages were used for creating graphics, for determining areas with specific characteristics for research purposes, and, by combining the layers into a single coverage, for including or excluding areas from resource calculations, and reporting coal resources using complex queries.

The areal extent of all of the layers of information for the Powder River Basin study was limited to the area of a box with boundaries just outside of the Powder River Basin. This box is not listed in our description of ARC/INFO coverages below. It is a tool used for clipping large coverages to a 

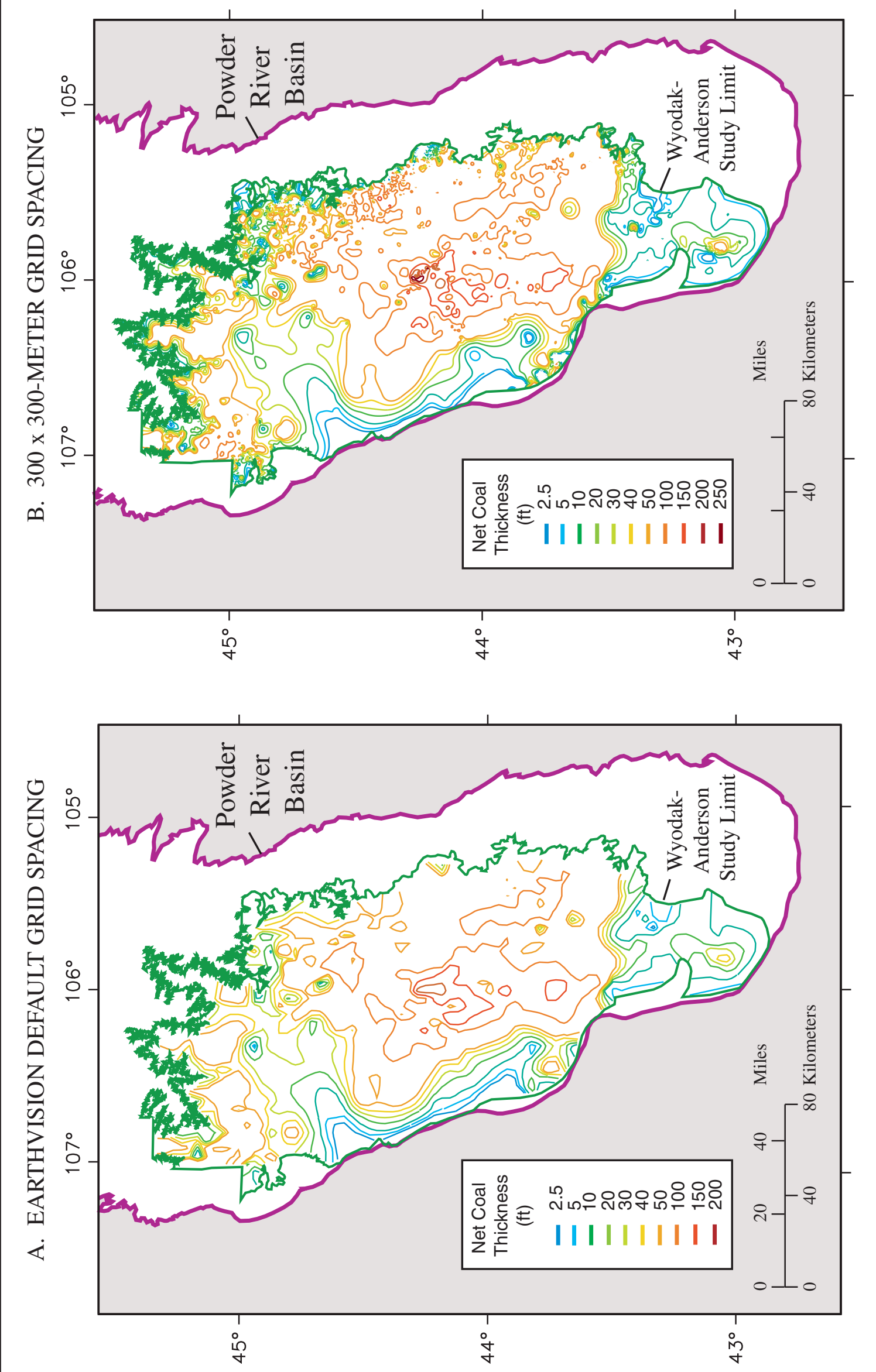

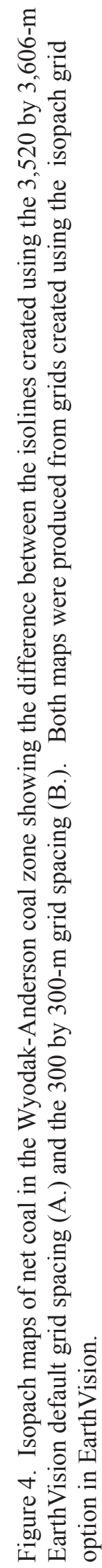



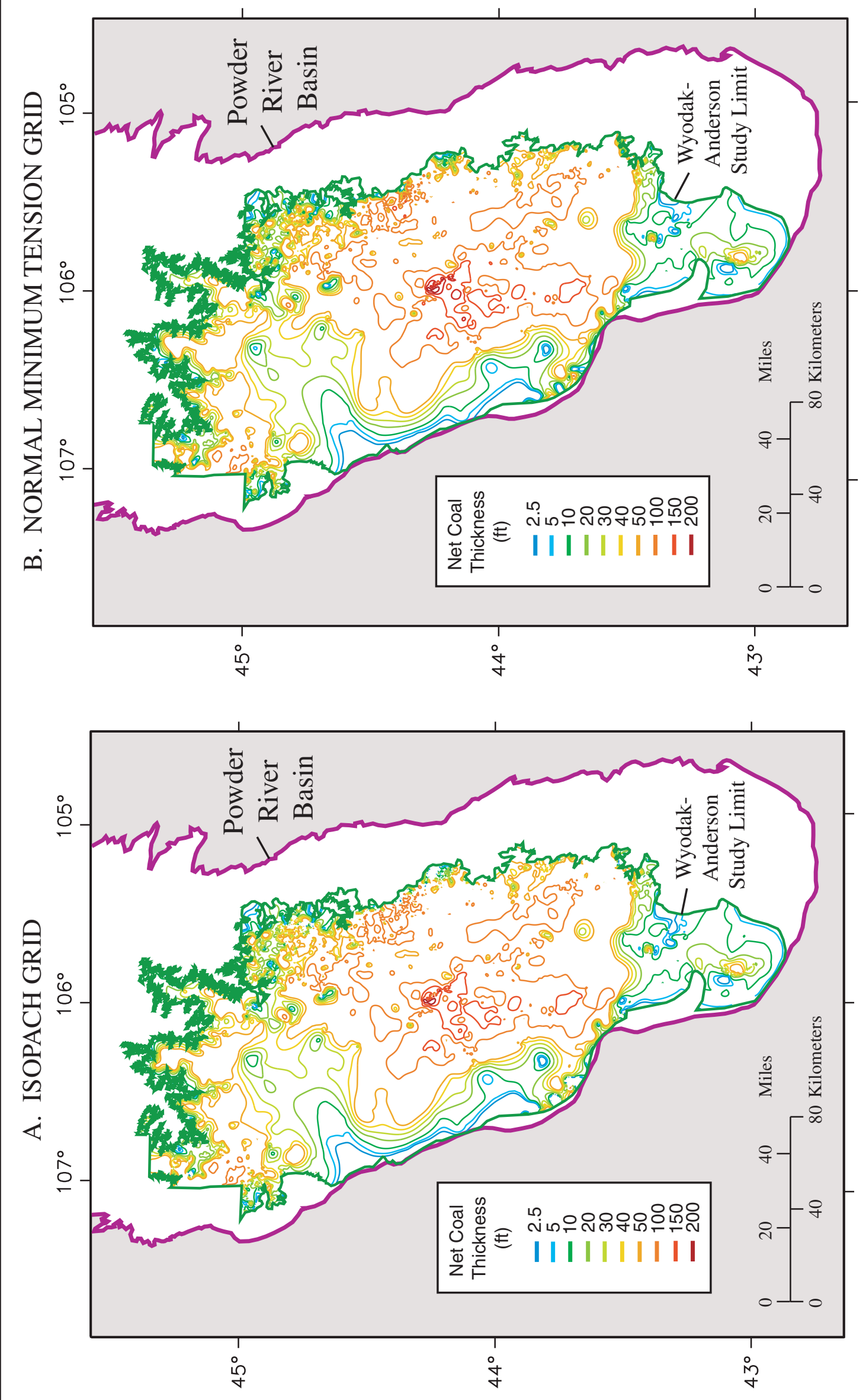

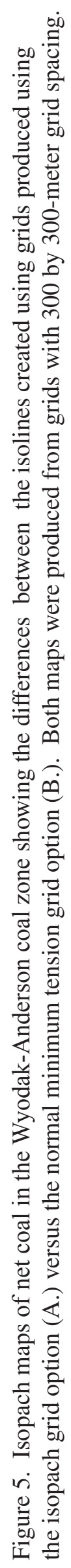


manageable size. All of the layered data were stored in the same projection used for the grid files and other files produced in EV. The layers of information (ARC/INFO coverages) that were used for this study, their use, the sources of information, and a general description of how the coverages were created are listed below.

State Boundary -- The state boundary coverage shows the boundary of Wyoming and Montana (figure 6 ) in the Powder River Basin area. The boundary is used for creating graphics and for reporting coal resources within each state (tables 1,2 , and 3). The coverage was created from a National state coverage from the U.S. Geological Survey National Mapping Division (1997). The original coverage was at a scale of 1:2,000,000 and was in Albers projection, with a first standard parallel of 29 degrees and 30 minutes, a second standard parallel of 45 degrees and 30 minutes, a central meridian of 96 degrees west longitude, and an origin of 23 degrees north latitude. The projection had 0 false northing and 0 false easting. We clipped-out parts of the state polygons for Montana, Wyoming, North Dakota, South Dakota, Nebraska, Colorado, and New Mexico using a polygon of the Northern Rocky Mountain and Great Plains region that we had digitized. The clipped coverage was projected to Lambert Conformal Conic with a central meridian of 107 degrees west longitude. This coverage is used for our regional studies. The Powder River Basin state coverage was created from the regional coverage by projecting the coverage to Lambert Conformal Conic with a central meridian of 106 degrees west longitude and clipped it to the Powder River Basin study area.

Counties -- The county coverage shows the location and extent of counties in the Powder River Basin area (figure 6). The original national coverage was obtained from the U.S. Geological Survey National Mapping Division (1997). The coverage was at a scale of 1:100,000 and was in Albers projection. The coverage was projected and clipped for use on a regional scale, and projected and clipped again for use in the Powder River Basin study area (as described above). The coverage is used for graphics and for reporting coal resources in tables.

Powder River Basin Boundary -- The Powder River Basin boundary is defined by the contacts of Tertiary/Cretaceous formations (figure 6). The coverage was digitized from 1:500,000 scale State maps of Montana (Ross and others, 1955) and Wyoming (Love and Christiansen, 1985). The northeast boundary was generalized (modified from Ross and others, 1955) along the Miles City Arch, a northwest, southeast trending arch east of the town of Miles City, Montana. The Powder River Basin boundary was used for creating graphics and for clipping some of the other coverages.

Wyodak-Anderson Study Limit -- This coverage shows the approximate lateral extent of the WyodakAnderson coal zone (figure 7). The boundary was created using published maps by Kent and Berlage (1980), Bryson and Bass (1973), Robinson and Culbertson (1984), Warren (1959), Baker (1929), Love and Christiansen (1985), and Ross and others (1955) and unpublished geologic maps by Romeo Flores and by William Culbertson of the U.S. Geological Survey. The boundary was generalized in some areas, to include small areas outside of the main boundary, and was refined by eliminating areas along the boundary where Wyodak-Anderson clinker had been mapped. This boundary was used for creating graphics and for clipping other coverages, including the net coal isopach map, the overburden isopach map, and the union coverage used for resource calculation.

Tribal Lands -- The tribal land coverage shows the boundary of the Northern Cheyenne and Crow Indian Reservations (figure 6). The coverage was generated from a land use and Federal land coverage in the Powder River Basin area, published by Biewick and others (1998). The coverage was used for graphic display and was also included in the union coverage to exclude the tribal lands from reported resource calculations. 


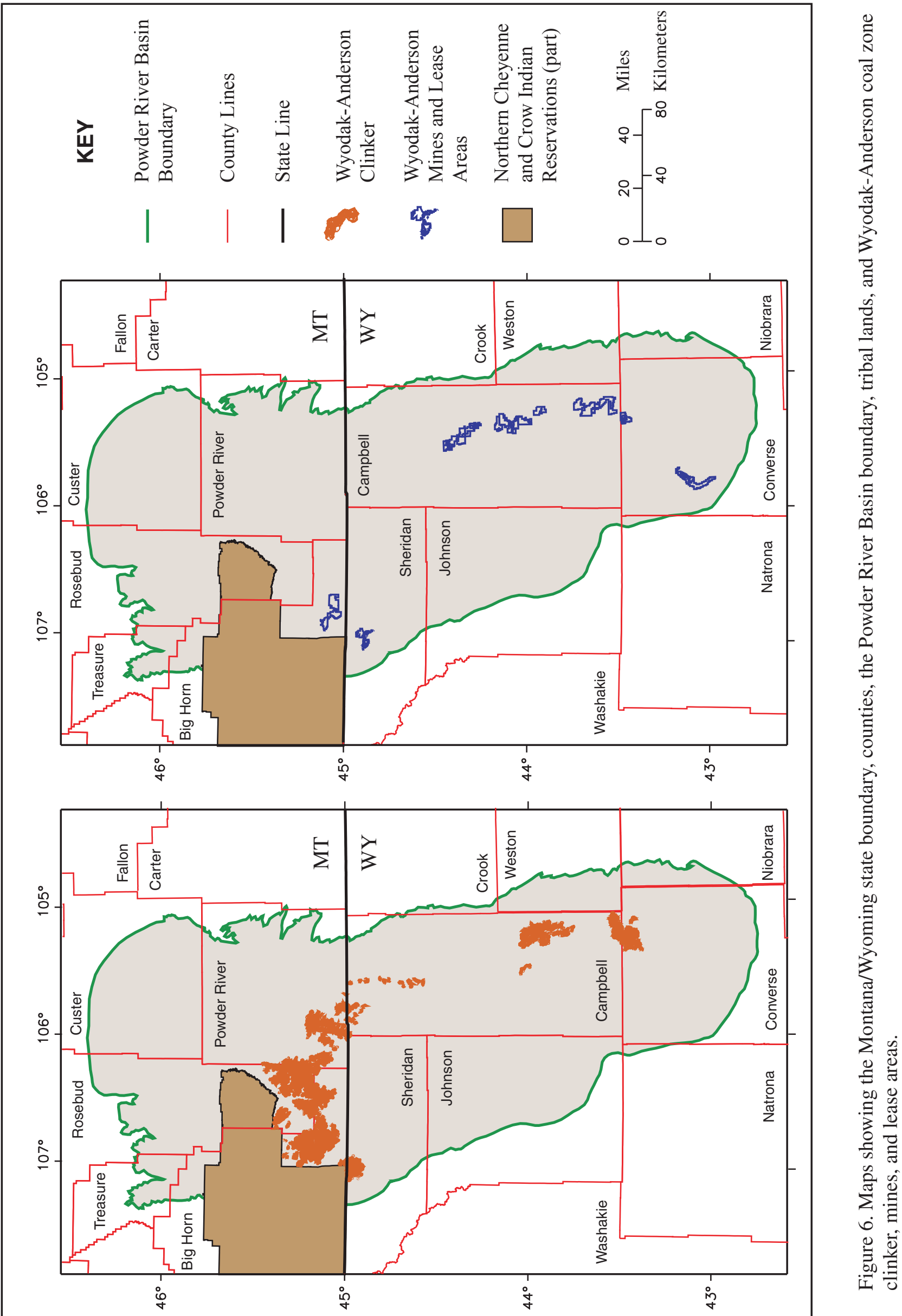




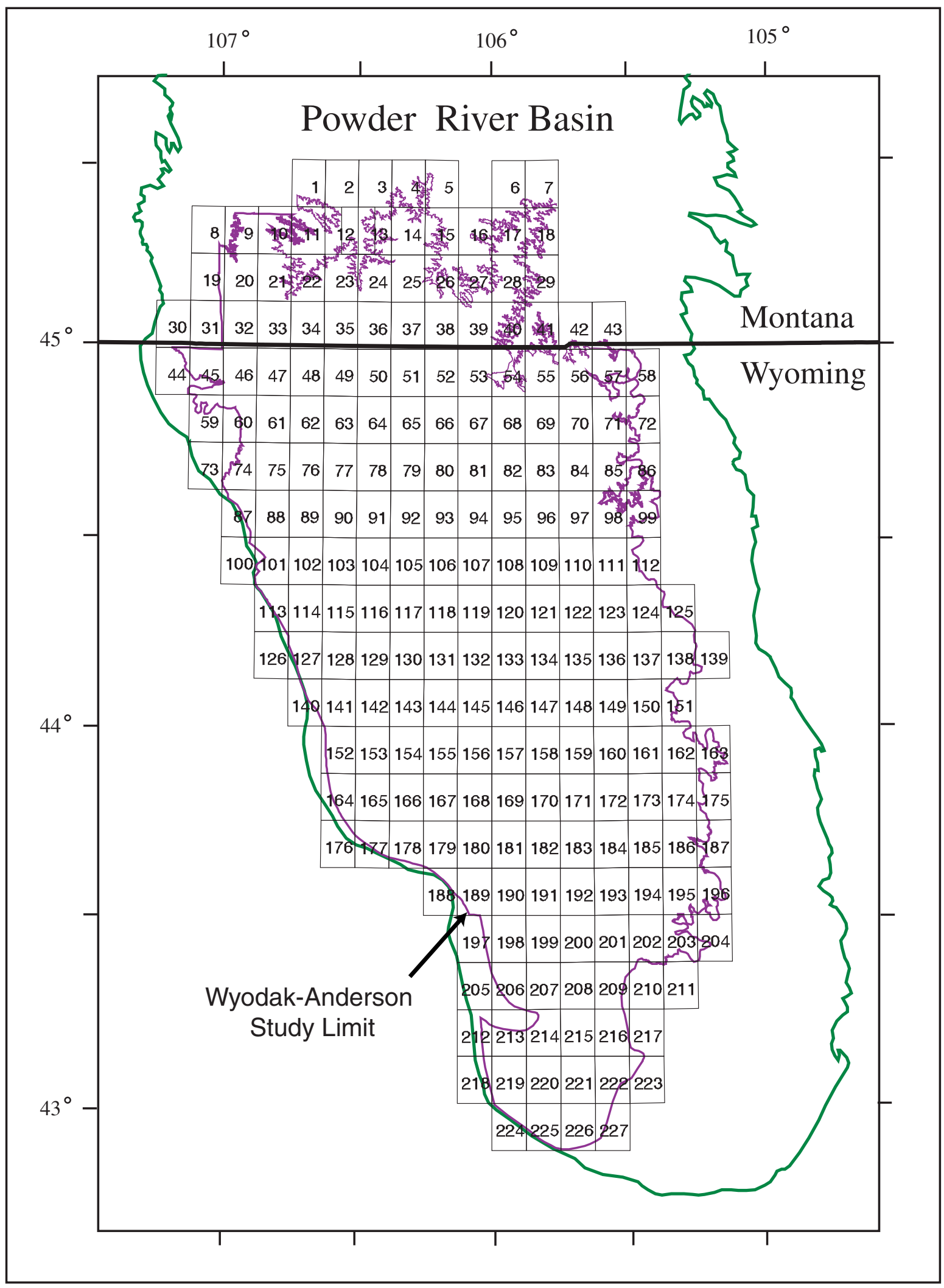

Figure 7. Map showing the location of 7.5-minute quadrangle maps in the study area. Quadrangle index numbers and names are shown on Table 1. 
Clinker --The clinker coverage shows areas of mapped Wyodak-Anderson clinker in the Powder River Basin area (figure 6). Our sources for this coverage are Daddow, 1986, Boyd and Van Ploeg, 1997, Heffern and others, 1993, Heffern, unpublished maps, and Kanizay, 1978. In the clinker areas, we do not have detailed information on how much of the Wyodak-Anderson coal is burned. Because of this, we used this coverage to eliminate all of the clinker polygon areas from our coal resource calculations.

Mines and Lease Boundaries--This coverage shows all of the Wyodak-Anderson mine areas and lease boundaries (figure 6). The boundaries came from several sources, including the Bureau of Land Management (1996), Kennecott Energy and others (not dated), and Dunrud and Osterwald (1980). The coverage is used for graphic displays and for clipping out areas where we did not want to report coal resource calculations. Coal resources in mine or lease areas were not reported because much of the proprietary data that we used was within those areas and information on the boundaries for mined out areas was incomplete.

7.5-minute Quadrangle Maps --The quadrangle coverage shows the location of all of the 7.5-minute quadrangle maps within the Wyodak-Anderson coal extent (figure 7 and table 4). The coverage was created by projecting and clipping an existing national coverage obtained from the U.S. Geological Survey National Mapping Division (1997). The scale of the original coverage was 1:24,000. The polygons were numbered sequentially from the upper left-hand corner to the lower right corner (left to right and top to bottom) and the names of the quadrangles were added to the polygon attribute table, using the numbering of the polygons to join the files. The coverage was used for reporting coal resources within each quadrangle area.

Point Locations --Two point coverages were created, one with all of the data points and the other with only the public data points included. The point data were obtained from our Powder River Basin stratigraphic database. The point coverage with all of the data was used to create the polygons for the reliability categories (described below). The point coverage containing only the public data was used for graphic display.

Reliability Categories --The reliability coverage consists of areas defined by categories described in Wood and others (1983). Reliability categories are areas within specific distances from a data point location (see figure 8 , which shows the reliability circles around public (nonproprietary) data points). To create the reliability circles, we created buffer zones in ARC/INFO around each of the data points at distances of $1 / 4$ mile, $3 / 4$ mile, and 3 miles. We then clipped the coverages using the Wyodak-Anderson coal extent boundary. Attributes to be used for reporting coal resource tonnages were added to the polygon attribute table. The reliability categories are: 0 to $1 / 4$ mile for measured, $1 / 4$ to $3 / 4$ mile for indicated, $3 / 4$ mile to 3 mile for inferred, and greater than 3 miles for hypothetical.

Federal Coal Ownership --This coverage shows Federal coal and Federal surface ownership (figure 9). The coverage was created from a land status and Federal mineral ownership coverage by Biewick and others (1998). The coverage was projected and clipped to our study area. We added an item to the polygon attribute table and generalized the attributes of the polygons into 4 categories: 1.) Federal coal yes and Federal surface yes (YY), 2.) Federal coal yes and Federal surface no (YN), 3.) Federal coal no and Federal surface yes (NY), and 4.) Federal coal no and Federal surface no (NN). Polygons in the coverage were then grouped on the basis of these four categories. The coverage was used for reporting coal resources by Federal ownership categories.

Digital Elevation Model (DEM) -- The DEM coverage is a representation of the topographic surface within the area of the Powder River Basin (figure 10). The Digital Elevation Model was obtained from the U.S. Geological Survey Global Land Information System (GLIS) (1997). Elevations in the DEM have a 500 by 500-m grid spacing. The DEM coverage was used for creating the overburden isopach map (as described below) and was also used for creating graphics. 


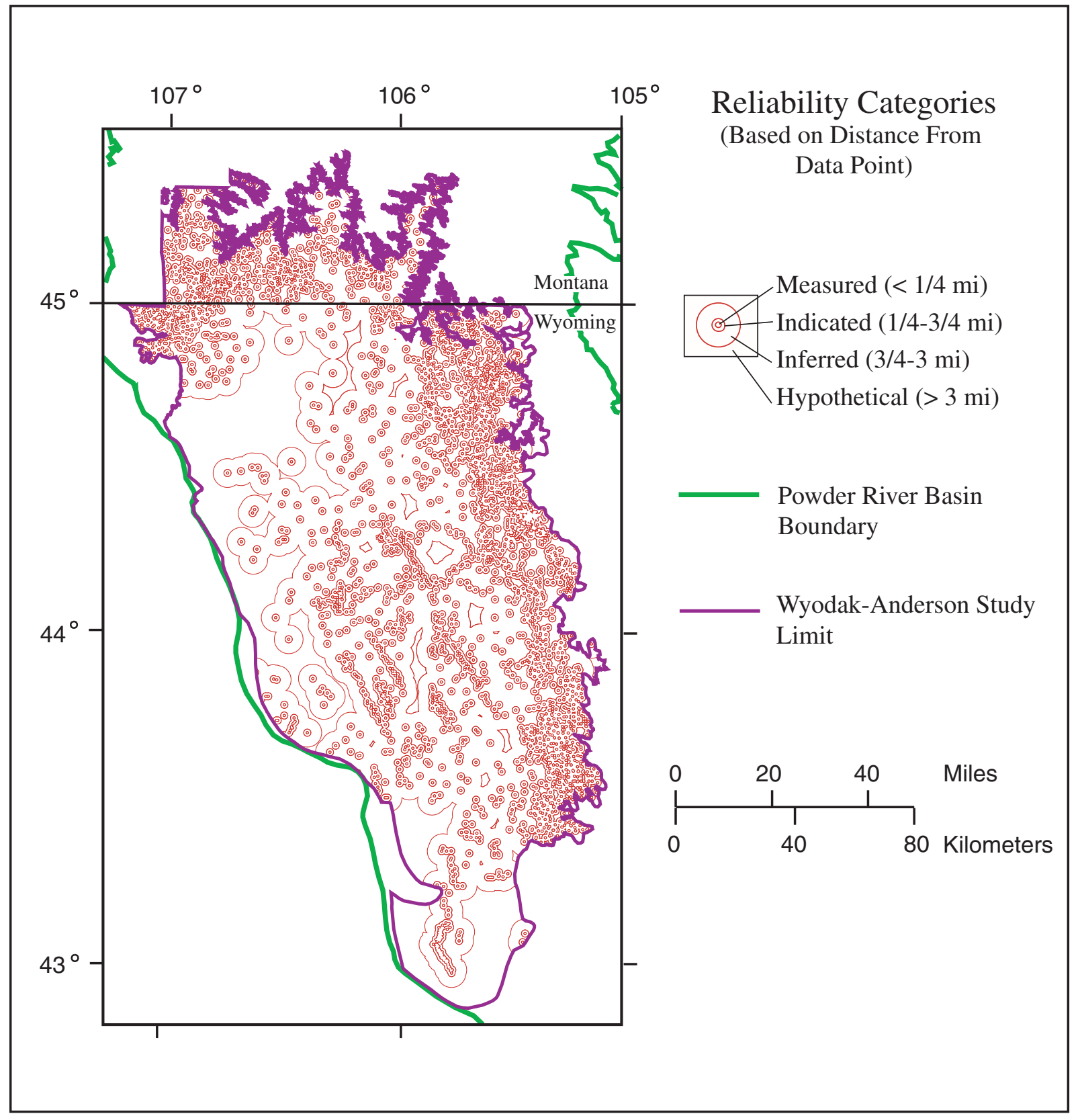

Figure 8. Map showing coal resource reliability categories in the Wyodak-Anderson study area, Powder River Basin, Wyoming and Montana. Only the areas around non-confidential (public) data points are shown on the map. 


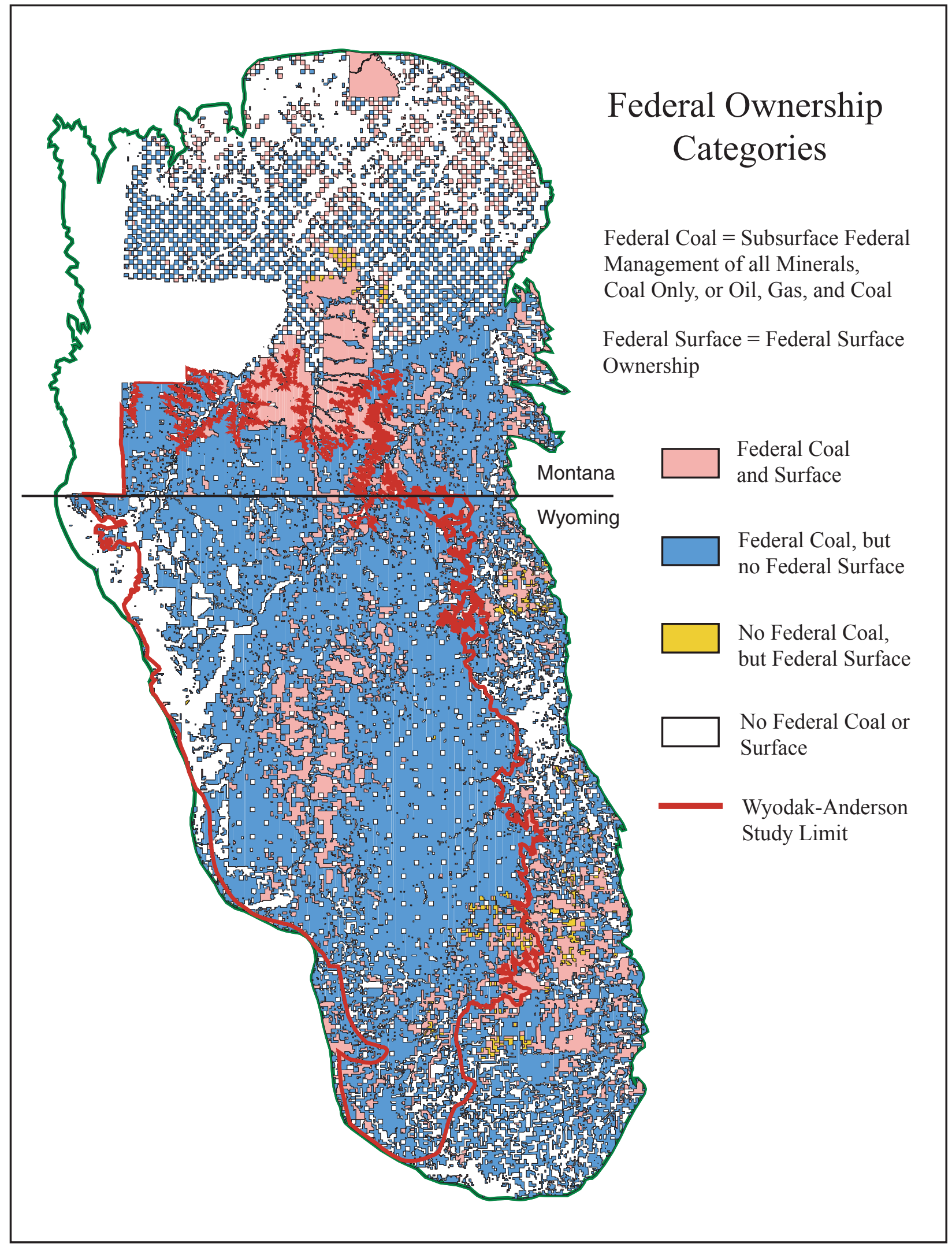

Figure 9. Map showing Federal ownership categories in the Powder River Basin. 
Overburden -- The overburden coverage shows polygons for overburden categories. Figure 11 shows an overburden map with detailed overburden categories. Overburden categories used for reporting coal resources of surface-minable, subbituminous (or lignite) coal are 0 to $100 \mathrm{ft}, 100$ to $200 \mathrm{ft}, 200$ to $300 \mathrm{ft}, 300$ to $400 \mathrm{ft}, 400$ to $500 \mathrm{ft}$, and greater than >500 ft. The overburden coverage is used for graphics and for reporting coal resources in tables. The overburden coverage was created by using a Digital Elevation Model (DEM) for the gridded topographic surface, creating a gridded surface for the elevation of the top of the Wyodak-Anderson coal zone (with the same grid spacing), and subtracting the two grids to get an overburden thickness grid. The overburden is measured from the topographic surface to the top of the uppermost coal bed in the Wyodak-Anderson coal zone. The overburden thickness grid was used to create an overburden isopach map, with a constant contour interval. The isopach map was saved as an output file. This file was used to generate a polygon coverage in ARC/INFO, by applying the same AML (Arc Macro Language) utilized for generating the net coal thickness coverage described below. As in the coal thickness coverage, the resulting coverage was queried, the polygons in each query set were labeled with text for the reporting categories, and the coverage was simplified by removing the lines between polygons that had the same text labels. A detailed overburden isopach map is shown in figure 11 .

Net Coal -- The net coal coverage contains polygons with thickness attributes of 0 to $2.5 \mathrm{ft}, 2.5$ to $5 \mathrm{ft}, 5$ to $10 \mathrm{ft}, 10$ to $20 \mathrm{ft}, 20$ to $30 \mathrm{ft}, 30$ to $40 \mathrm{ft}, 40$ to $50 \mathrm{ft}, 50$ to $100 \mathrm{ft}, 100$ to $150 \mathrm{ft}, 150$ to $200 \mathrm{ft}$, 200 to $250 \mathrm{ft}$, and 250 to $285 \mathrm{ft}$. Within EV, the 500 by $500-\mathrm{m}$ net coal isopach grid was multiplied by 100 and the grid was made into an unlabelled isopach map with a constant contour interval of $250 \mathrm{ft}$. The map was saved as an ASCII file and modified using a custom program (ismarc). The ASCII file was then generated into a polygon coverage using an AML (ARC Macro Language) program in ARC/INFO. The AML clipped the contour lines to the WyodakAnderson coal extent and assigned coal thickness values to the resulting polygons (attributed as the mean of the values of the contour lines bounding each polygon). The thickness values were then divided by 100 to calculate back to the correct net coal thickness for the polygons. An item was added to the polygon attribute table for the polygon coverage, and text labels were assigned to the polygons for the coal thickness categories listed above. The polygons in the coverage were then grouped based on the text labels. This ARC/INFO coverage was used in the union coverage for reporting resources by coal thickness categories in Ellis and others (1998). An additional net coal isopach map was produced in EV from a grid clipped to the Wyodak-Anderson study limit. This map is used for graphic display (figure 12). For our comparison of resources calculated using the isopach and NMT grid options, we created separate net coal thickness coverages. These coverages were each combined with the other layered information to make separate union coverages, which were used with the appropriate grids in EV to calculate coal resources.

\section{UNION COVERAGE}

Coverages included in the ARC/INFO union coverage are: state, county, tribal land, clinker, mines and lease boundaries, 7.5-minute quadrangle maps, reliability, federal ownership, overburden, and net coal. The coverages were combined to create a union coverage with many attributes for each polygon. When the coverages were unioned, coverages that had many of the same boundaries (federal ownership, counties, states, 7.5-minute quadrangles) produced thin polygons (slivers) where the coverages did not match exactly. The overburden and net coal thickness coverages were the last to be added to the unioned coverage. After combining of all of the coverages, the coverage was clipped to the Wyodak-Anderson coal extent. Slivers in the coverage were removed by eliminating polygons that were less than 25,000 square meters in area. Additional problematic polygons were edited manually in ArcView (ESRI, 1998b). Text fields that aid in the production of coal resource tables were added to the final unioned coverage. A portion of the union coverage, in the Sheridan area of the Powder River Basin, is shown in figure 13. This figure illustrates the complexity of the coverage. Two union coverages were created with all layers of information identical except for coal thickness. One union 


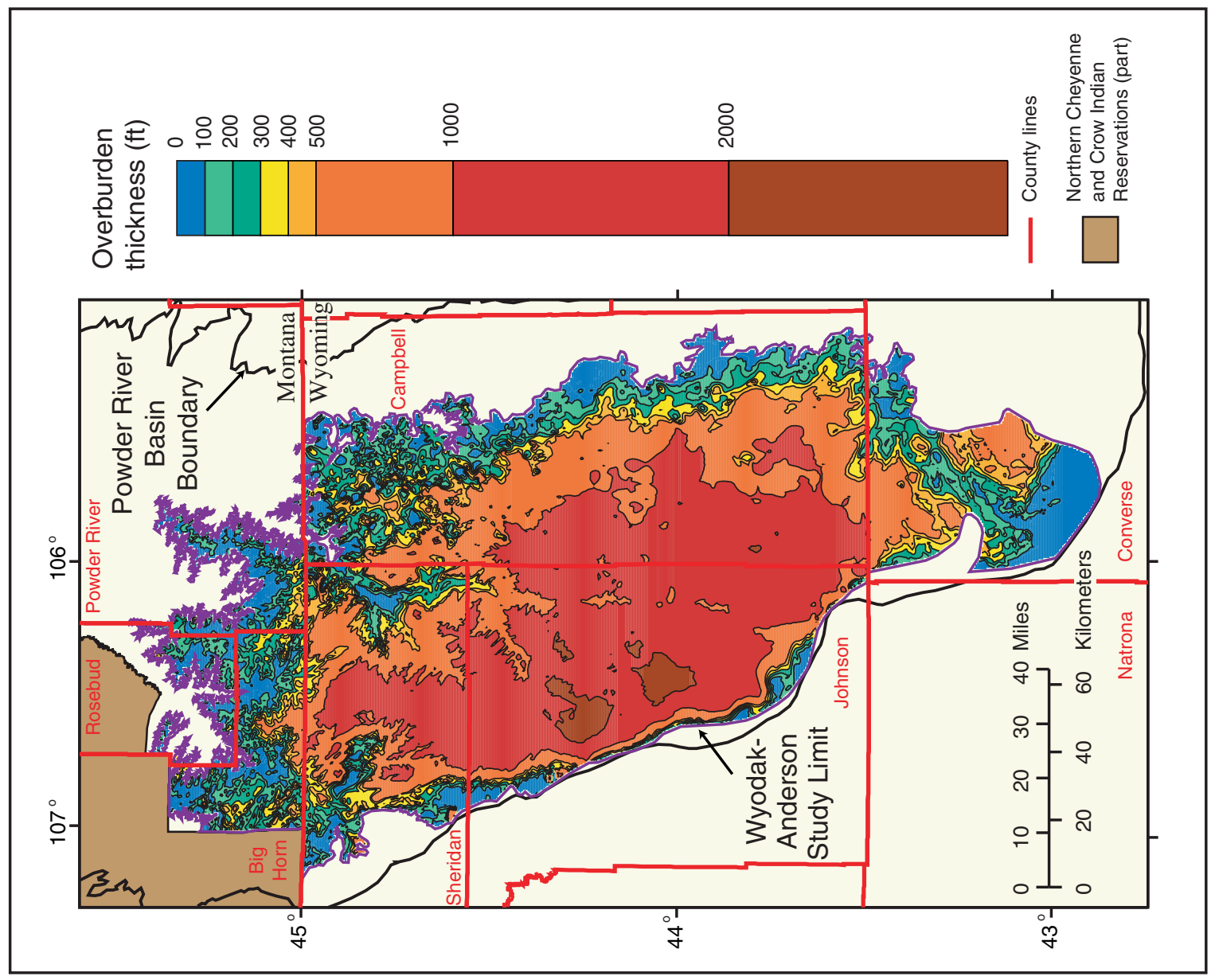

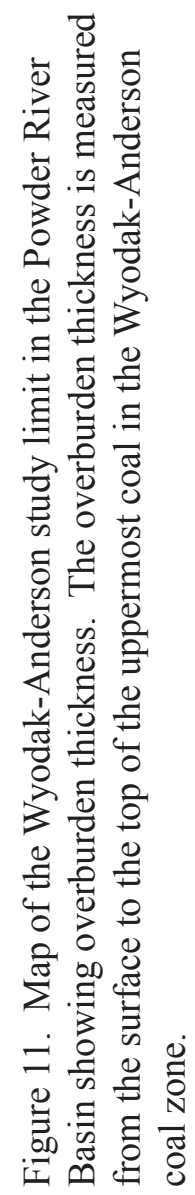
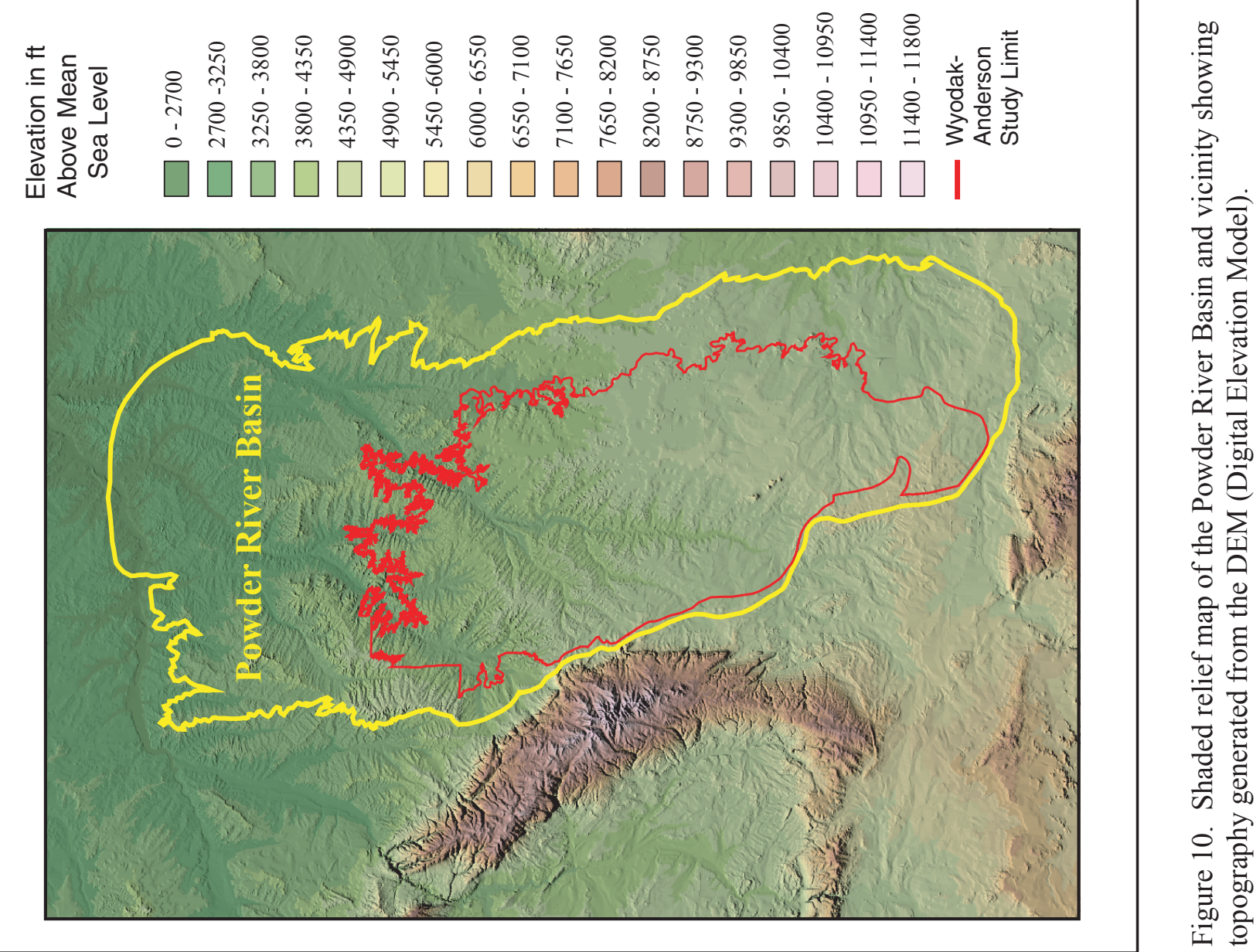


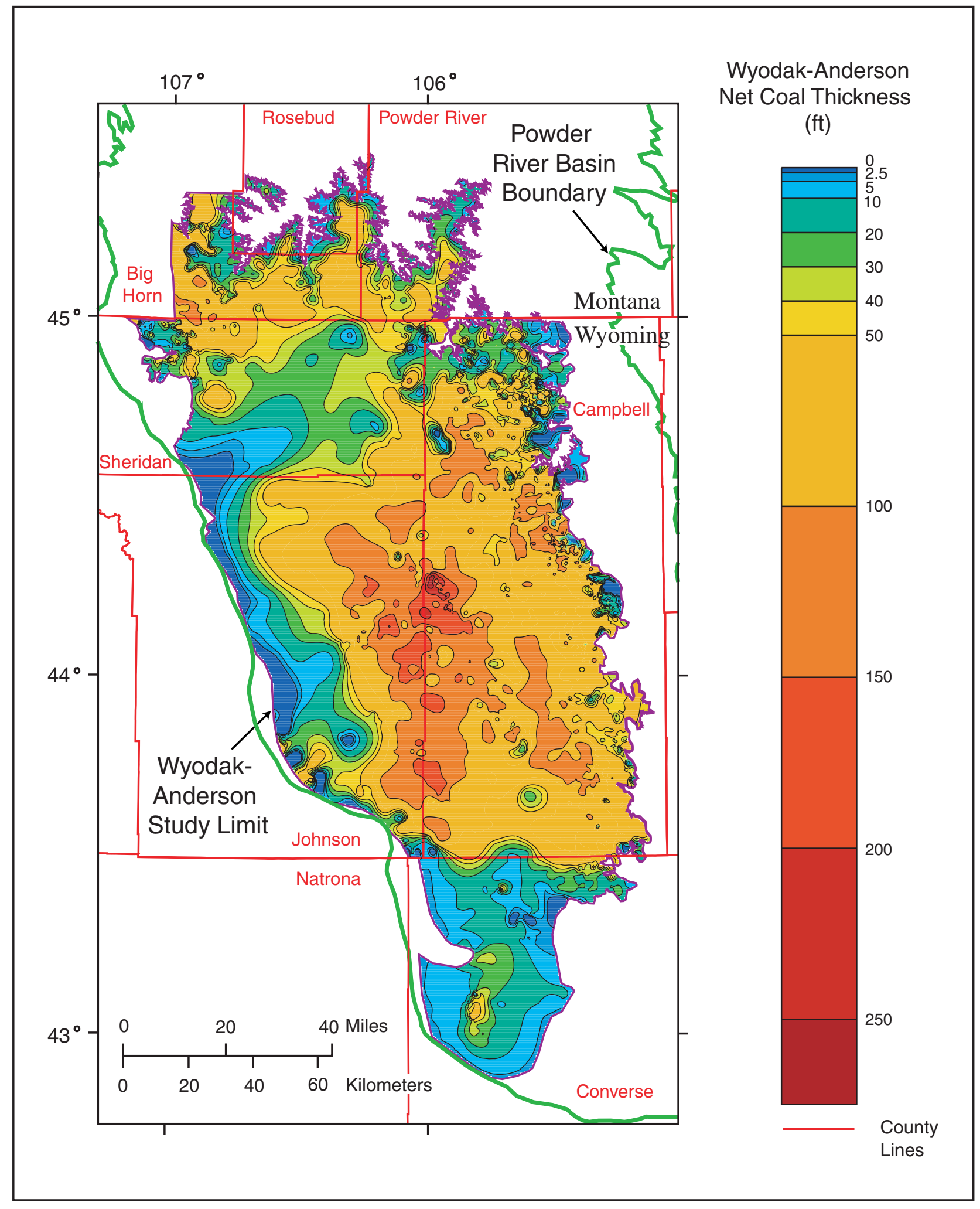

Figure 12. Net coal isopach map of the Wyodak-Anderson coal zone in the Powder River Basin, Wyoming and Montana. 


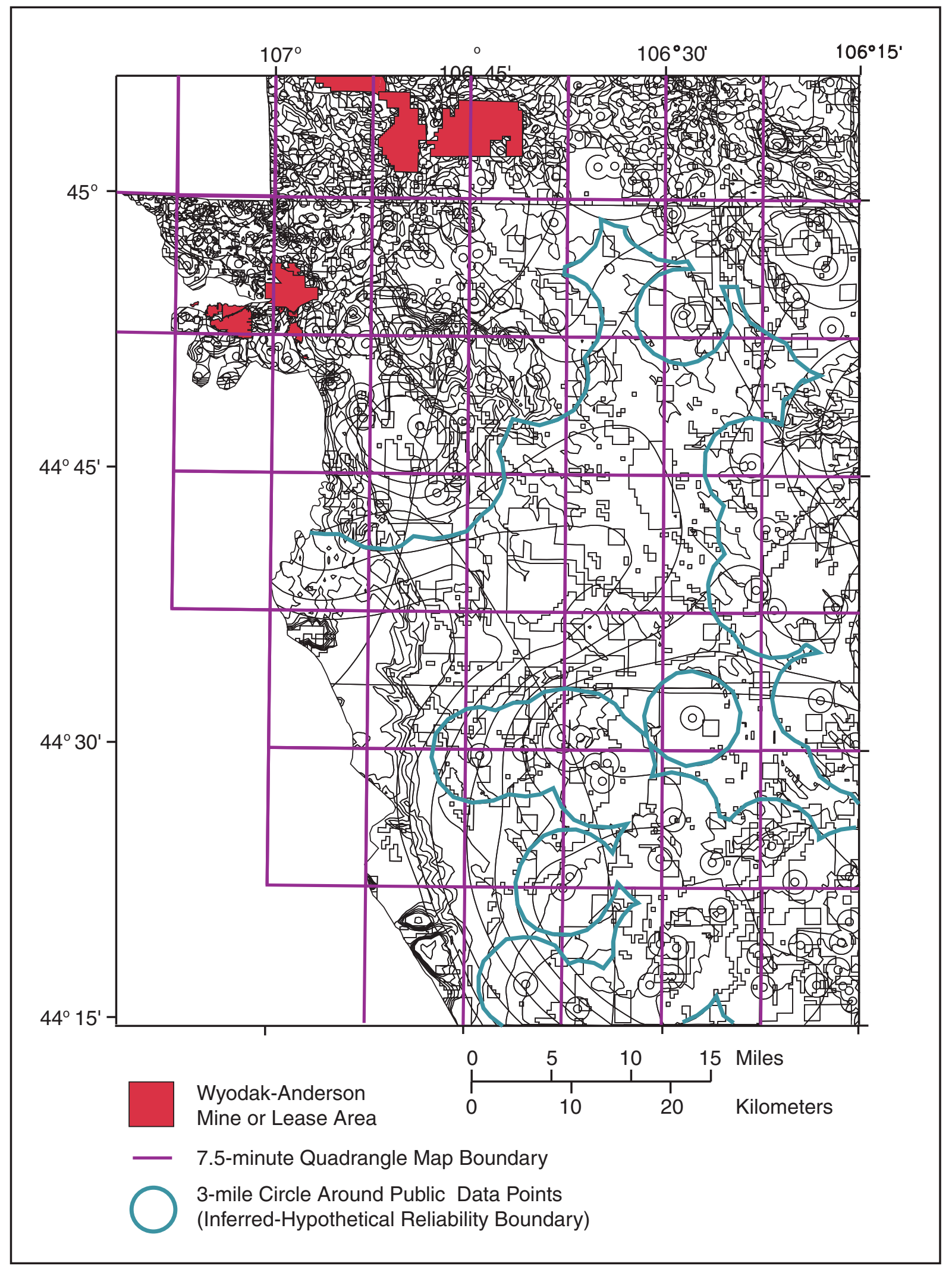

Figure 13. Map showing union coverage polygons used for the study of the Wyodak-Anderson coal zone in a portion of the study area near Sheridan, Wyoming. The mine and lease areas, 7.5-minute quadrangles, inferred-hypothetical reliability boundary are shown in color for a reference. (The coverage is too complex to effectively show each layer in a different color.) 
coverage contained polygons created in EV using the isopach gridding option and the other used the polygons created using the NMT grid option. Coal resources were calculated in EV using the two union coverages and various coal thickness grids to compare the results (tables 2 through 6).

\section{COMPARISON OF RESOURCE CALCULATIONS}

For the calculation of coal resources, we tested two methods for calculating volumetrics, the ARC/INFO method and the EarthVision (Dynamic Graphics Inc., 1997) method. The ARC/INFO (ESRI, 1998a) method involved using information from the union coverage polygon attribute table to calculate the amount of short tons of coal in each polygon. The calculations could be performed in ARC/INFO, ArcView, or in relational database software or spreadsheet software. The method we used was to import the polygon attribute table(s) from the union coverage(s) into Excel (Microsoft, 1997). In Excel, we created several new calculated fields. First, we calculated the acres in each polygon by multiplying the area (in square meters) by .0002471 acres per square meter. The next field was acre-ft, which was calculated by multiplying the acres in each polygon by the mean thickness value of each polygon. The mean thickness value of polygons with attribute values of 0 to $2.5 \mathrm{ft}$ was $1.25 \mathrm{ft}, 2.5$ to $5 \mathrm{ft}$ was $3.75 \mathrm{ft}, 5$ to $10 \mathrm{ft}$ was $7.50 \mathrm{ft}, 10$ to $20 \mathrm{ft}$ was $15 \mathrm{ft}, 20$ to $30 \mathrm{ft}$ was $25 \mathrm{ft}, 30$ to $40 \mathrm{ft}$ was $35 \mathrm{ft}, 40$ to $50 \mathrm{ft}$ was $45 \mathrm{ft}, 50$ to $100 \mathrm{ft}$ was $75 \mathrm{ft}, 100$ to $150 \mathrm{ft}$ was $125 \mathrm{ft}, 150$ to $200 \mathrm{ft}$ was $175 \mathrm{ft}, 200$ to 250 was $225 \mathrm{ft}$, and greater than $250 \mathrm{ft}$ was $275 \mathrm{ft}$. To calculate the amount of short tons of coal in each polygon, the acre-ft value was multiplied by a density conversion factor of 1,770 short tons of subbituminous coal per acre-ft (Wood and others, 1983). The polygons in areas where resources were not to be reported (Wyodak-Anderson clinker areas, mines, and lease areas, tribal land, and areas containing less than $2.5 \mathrm{ft}$ of coal) were then deleted from the data set. Tables reporting coal resources by category were created using the Excel pivot table tool.

The EV method uses a combination of ARC/INFO and EV to calculate volumetrics. The polygons from the ARC/INFO union coverage were imported into EV, and the volumetrics were calculated using the area of the union coverage polygons and the grid values from the net coal thickness grid. For the comparison of coal resources calculated using different grid sizes and grid options, we imported several different coverages. To avoid problems resulting from grids created using coarse grid spacings, we used the formula processor in EV to add grid nodes to the 1,000 by 1,000-m, 800 by $800-\mathrm{m}$, and 500 by $500-\mathrm{m}$ isopach and NMT grids. This operation retained the values of the coarse grids, but added grid nodes at the same spacing as the 300 by $300-\mathrm{m}$ grid.

Each union coverage was brought into EV using the utility import, polygons were labeled using the polygon id, and the union coverage was saved as a polygon file. The polygon file was then selected and the projection of the data was defined in the file header. Resources were then calculated with the EV volumetrics tool, using the unioned polygon and the unclipped detailed coal thickness grid. Although calculations were performed using several different grids, the 300 by $300-\mathrm{m}$ isopach grid was used for the final resource calculations. In the volumetrics utility, a 0 layer was added; the constant yield, to convert from acre-ft to short tons, was assigned as 1770; volumetrics were assigned as short tons; and the measurement was determined to be in acre-ft.

As a result of calculation, the EV volumetrics report contains header information, the polygon id, positive area, and the amount of short tons for each polygon. To modify the report, we ran it through a custom program (evrpt) to strip off the headers and calculate the net coal thickness within each polygon. The information from the volumetrics report was then merged with the union coverage polygon attribute table.

To create tables reporting resource calculations by category and combinations of attributes, we exported the ARC/INFO polygon attribute table into a spreadsheet (Excel) software program. The file was modified to include additional text fields to aid in the creation of resource tables and the tables were created using the pivot table tool. Final resource tables are included in Ellis and others, 1999.

Comparisons of resource calculations performed using different grid spacings, grid options, and methods are shown in tables $1,2,3,5$ and 6 . 
Table 1. Comparison of EV coal resource calculations of the Wyodak-Anderson coal zone using 300 by $300-\mathrm{m}$ isopach versus 300 by 300-m NMT grid options, reported by state and county. Resources are reported in millions of short tons (MST) rounded to three significant figures. Percentages are rounded to two significant figures. Columns will not sum to match the total due to independent rounding.

\begin{tabular}{|c|c|c|c|c|}
\hline State & County & $\begin{array}{c}\text { Isopach Grid Option } \\
\text { Total (MST) }\end{array}$ & $\begin{array}{c}\text { NMT Grid Option } \\
\text { Total (MST) }\end{array}$ & $\begin{array}{l}\text { Percent Difference in } \\
\text { Unrounded } \mathrm{MST}^{1}\end{array}$ \\
\hline \multirow[t]{3}{*}{ Montana } & BIG HORN & 28,500 & 28,200 & $1.02 \%$ \\
\hline & POWDER RIVER & 10,900 & 10,900 & $0.29 \%$ \\
\hline & ROSEBUD & 2,790 & 2,650 & $5.1 \%$ \\
\hline \multicolumn{2}{|c|}{ Montana Total } & 42,300 & 41,800 & $1.1 \%$ \\
\hline \multirow[t]{4}{*}{ Wyoming } & CAMPBELL & 282,000 & 282,000 & $0.11 \%$ \\
\hline & CONVERSE & 15,300 & 15,200 & $0.21 \%$ \\
\hline & JOHNSON & 159,000 & 159,000 & $0.22 \%$ \\
\hline & SHERIDAN & 52,300 & 52,100 & $0.29 \%$ \\
\hline \multicolumn{2}{|c|}{ Wyoming Total } & 509,000 & 508,000 & $0.16 \%$ \\
\hline \multicolumn{2}{|c|}{ Grand Total } & 551,000 & 550,000 & $0.24 \%$ \\
\hline
\end{tabular}

1. Percent difference in unrounded MST = (to calculate a positive percentage) subtracted the unrounded total of millions of short tons calculated using the NMT grid option from the unrounded total of millions of short tons calculated using the isopach grid option, divided by the unrounded total of millions of short tons using the isopach grid option, and multiplied the fraction by 100 to get a percentage representative of how much more MST were calculated using the isopach grid than using the NMT grid.

Table 2. Comparison of EV coal resource calculations of the Wyodak-Anderson coal zone using net coal thickness grids with different grid spacings reported by state and county. All of the grids were created using the EV isopach grid option. Resources are reported in millions of short tons (MST) with three significant figures. Percent is rounded to two significant figures. Columns will not sum to match the totals due to independent rounding.

\begin{tabular}{|c|c|c|c|c|c|c|}
\hline \multirow[b]{2}{*}{ State } & \multirow[b]{2}{*}{ County } & \multicolumn{4}{|c|}{ Coal Resources in Millions of Short Tons (MST) } & \multirow{2}{*}{$\begin{array}{l}\text { Maximum } \\
\text { Percent } \\
\text { Difference in } \\
\text { Unrounded } \\
\text { MST }^{1} \\
\end{array}$} \\
\hline & & $\begin{array}{l}300 \text { by } \\
\text { 300-m Grid } \\
\text { Spacing }\end{array}$ & $\begin{array}{l}500 \text { by } \\
500-\mathrm{m} \text { Grid } \\
\text { Spacing }\end{array}$ & $\begin{array}{c}800 \text { by } \\
\text { 800-m Grid } \\
\text { Spacing }\end{array}$ & $\begin{array}{c}1,000 \text { by } \\
1,000-m \text { Grid } \\
\text { Spacing }\end{array}$ & \\
\hline \multirow[t]{3}{*}{ Montana } & BIG HORN & 28,500 & 28,600 & 28,600 & 28,700 & $0.41 \%$ \\
\hline & $\begin{array}{l}\text { POWDER } \\
\text { RIVER }\end{array}$ & 10,900 & 11,000 & 11,000 & 10,900 & $1.3 \%$ \\
\hline & ROSEBUD & 2,790 & 2,810 & 2,780 & 2,800 & $0.89 \%$ \\
\hline \multicolumn{2}{|c|}{ Montana Total } & 42,300 & 42,400 & 42,400 & 42,400 & $0.41 \%$ \\
\hline \multirow[t]{4}{*}{ Wyoming } & CAMPBELL & 282,000 & 284,000 & 282,000 & 284,000 & $0.71 \%$ \\
\hline & CONVERSE & 15,300 & 15,200 & 15,400 & 15,200 & $0.89 \%$ \\
\hline & JOHNSON & 159,000 & 159,000 & 159,000 & 159,000 & $0.32 \%$ \\
\hline & SHERIDAN & 52,300 & 51,800 & 52,500 & 51,800 & $1.3 \%$ \\
\hline \multicolumn{2}{|c|}{ Wyoming Total } & 509,000 & 510,000 & 509,000 & 510,000 & $0.30 \%$ \\
\hline \multicolumn{2}{|c|}{ Grand Total } & 551,000 & 553,000 & 551,000 & 553,000 & $0.29 \%$ \\
\hline
\end{tabular}

1. Percent difference in unrounded MST $=$ (to calculate a positive percentage) subtracted the smallest total of unrounded total of millions of short tons from the largest total of unrounded total of millions of short tons, divided by the largest unrounded total of millions of short tons, and multiplied the fraction by 100 to get a percentage representative of the maximum percent difference in millions of short tons calculated using the four different grid spacings. 
Table 3. Comparison of average net coal thickness and total coal resources for the Wyodak-Anderson coal zone calculated using EarthVision (EV) versus ARC/INFO (ARC) methods, reported by state and county. The calculations for the EV method used a 300 by $300-\mathrm{m}$ coal thickness isopach grid. Net coal thickness and percent are rounded to two significant figures. Resources are reported in millions of short tons (MST) with three significant figures. Resources will not sum to match totals due to independent rounding.

\begin{tabular}{|c|c|c|c|c|}
\hline State & County & Data & Total & $\begin{array}{l}\text { Percent Difference in } \\
\text { Unrounded MST }\end{array}$ \\
\hline \multirow[t]{3}{*}{ Montana } & BIG HORN & $\begin{array}{l}\text { Average of EV net coal thk } \\
\text { Average of ARC net coal thk } \\
\text { Sum of EV MST } \\
\text { Su. } \\
\text { Sum of ARC MST } \\
\text { S. }\end{array}$ & $\begin{array}{r}55 \\
58 \\
28,500 \\
30,900\end{array}$ & $7.7 \%$ \\
\hline & POWDER RIVER & $\begin{array}{l}\text { Average of EV net coal thk } \\
\text { Average of ARC net coal thk } \\
\text { A. } \\
\text { Sum of EV MST } \\
\text { Sum of ARC MST } \\
\text { Sum }\end{array}$ & $\begin{array}{r}33 \\
37 \\
10,900 \\
12,200\end{array}$ & $11 \%$ \\
\hline & ROSEBUD & $\begin{array}{l}\text { Average of EV net coal thk }{ }^{1 .} \\
\text { Average of ARC net coal thk }{ }^{2 .} \\
\text { Sum of EV MST } \\
\text { Sum of ARC MST }\end{array}$ & $\begin{array}{r}22 \\
24 \\
2,790 \\
3,070\end{array}$ & $9.1 \%$ \\
\hline \multicolumn{3}{|c|}{$\begin{array}{l}\text { Montana Average of EV coal thk } \\
\text { Montana Average of ARC coal thk } \\
\text { Montana Sum of EV MST } \\
\text { Montana Sum of ARC MST } \\
\text { M. }\end{array}$} & $\begin{array}{r}41 \\
44 \\
42,300 \\
46,200\end{array}$ & $8.6 \%$ \\
\hline \multirow[t]{4}{*}{ Wyoming } & CAMPBELL & $\begin{array}{l}\text { Average of EV net coal thk }{ }^{1 .} \\
\text { Average of ARC net coal thk } \\
\text { Sum of EV MST } \\
\text { Sum of ARC MST }^{4}\end{array}$ & $\begin{array}{r}63 \\
65 \\
282,000 \\
286,000\end{array}$ & $1.3 \%$ \\
\hline & CONVERSE & $\begin{array}{l}\text { Average of EV net coal thk } \\
\text { Average of ARC net coal thk } \\
\text { Sum of EV MST }^{3 .} \\
\text { Sum of ARC MST } \\
\text { S. }^{2}\end{array}$ & $\begin{array}{r}15 \\
16 \\
15,300 \\
16,200\end{array}$ & $5.6 \%$ \\
\hline & JOHNSON & $\begin{array}{l}\text { Average of EV net coal thk }{ }^{1 .} \\
\text { Average of ARC net coal thk } \\
\text { Sum of EV MST }^{3 .} \\
\text { Sum of ARC MST } \\
\text { Sum }^{2}\end{array}$ & $\begin{array}{r}67 \\
68 \\
159,000 \\
161,000\end{array}$ & $1.0 \%$ \\
\hline & SHERIDAN & $\begin{array}{l}\text { Average of EV net coal thk } \\
\text { Average of ARC net coal thk } \\
\text { Sum of EV MST }^{3 .} \\
\text { Sum of ARC MST }\end{array}$ & $\begin{array}{r}35 \\
36 \\
52,300 \\
55,100\end{array}$ & $5.1 \%$ \\
\hline \multicolumn{3}{|c|}{$\begin{array}{l}\text { Wyoming average of EV net coal thk } \\
\text { Wyoming average of ARC net coal thk } \\
\text { Wyoming sum of EV MST }^{3 .} \\
\text { Wyoming sum of ARC MST }^{4}\end{array}$} & $\begin{array}{r}52 \\
54 \\
509,000 \\
518,000\end{array}$ & $1.8 \%$ \\
\hline
\end{tabular}


Table 3. Continued.

\begin{tabular}{|c|c|c|}
\hline Montana and Wyoming & Total & $\begin{array}{l}\text { Percent Difference in } \\
\text { Unrounded MST }\end{array}$ \\
\hline Total average of EV net coal thk ${ }^{1}$ & 50 & \\
\hline Total average of ARC net coal thk ${ }^{2 .}$ & 52 & \\
\hline Total sum of EV MST ${ }^{3}$ & 551,000 & \\
\hline Total sum of ARC MST ${ }^{4}$ & 564,000 & $2.3 \%$ \\
\hline
\end{tabular}

${ }^{1}$ EV coal thk = net coal thickness calculated from the short tons and the positive area from the EV volumetrics.

2. ARC coal thk = net coal thickness of the polygons. Represented by the mean value between the contour lines produced in EV and imported into ARC/INFO to produce the net coal isopach coverage. The level of detail decreases with increased coal thickness. Polygon categories for calculations (and corresponding thickness ranges) in $\mathrm{ft}$ are 2.5 to 5 (3.75), 5 to 10 (7.5), 10 to 20 (15), 20 to 30 (25), 30 to 40 (35), 40 to 50 (45), 50 to 100 (75), 100 to 150 (125), 150 to 200 (175), 200 to 250 (225), 250 to 300 (275).

${ }^{3 .} \mathrm{EV} \mathrm{MST}=\mathrm{coal}$ resources (in millions of short tons) taken from the number of short tons from the EV volumetrics report divided by $1,000,000$.

4. ARC MST = coal resources (in millions of short tons) calculated from the area of the polygons (in square meters) multiplied by .0002471 acres per square meter to calculate acres, acres multiplied by ARC coal thk to calculate acre-ft, acre-ft multiplied by 1,770 short tons of subbituminous coal per acre-ft to calculate short tons, and short tons divided by 1,000,000 to calculate millions of short tons.

5. Percent difference in unrounded MST = (to calculate a positive percentage) subtracted the unrounded total of millions of short tons calculated using the EV method from the unrounded total of millions of short tons calculated using the ARC/INFO method, divided by the unrounded total of millions of short tons using the ARC/INFO method, and multiplied the fraction by 100 to get a percentage representative of how much more MST were calculated using the ARC/INFO method than using the EV method. 
Table 4. Key to 7.5-minute quadrangle maps in the study area. Map locations are shown in figure 7.

\begin{tabular}{|c|c|c|c|}
\hline Number & 7.5-minute Quadrangle Map & Number & 7.5-minute Quadrangle Map \\
\hline 1 & COOK CREEK BUTTE & 56 & CORRAL CREEK \\
\hline 2 & CLUBFOOT CREEK & 57 & HOMESTEAD DRAW \\
\hline 3 & BIRNEY DAY SCHOOL & 58 & ROCKY BUTTE \\
\hline 4 & GREEN CREEK & 59 & HULTZ DRAW \\
\hline 5 & KING MOUNTAIN & 60 & SHERIDAN \\
\hline 6 & THREEMILE BUTTES & 61 & WYARNO \\
\hline 7 & SONNETTE & 62 & JONES DRAW \\
\hline 8 & SPRING CREEK RANCH & 63 & S R SPRINGS \\
\hline 9 & KIRBY & 64 & SHULER DRAW \\
\hline 10 & TAINTOR DESERT & 65 & GARDNER GULCH \\
\hline 11 & BIRNEY SW & 66 & FAWN DRAW \\
\hline 12 & BIRNEY & 67 & CABIN CREEK SE \\
\hline 13 & BROWNS MOUNTAIN & 68 & KLINE DRAW \\
\hline 14 & POKER JIM BUTTE & 69 & RESERVOIR CREEK \\
\hline 15 & FORT HOWES & 70 & HOMESTEAD DRAW SW \\
\hline 16 & GOODSPEED BUTTE & 71 & WHITE TAIL BUTTE \\
\hline 17 & PHILLIPS BUTTE & 72 & ROCKY BUTTE SW \\
\hline 18 & HODSDON FLATS & 73 & BEAVER CREEK HILLS \\
\hline 19 & BAR V RANCH NE & 74 & BIG HORN \\
\hline 20 & HALF MOON HILL & 75 & BUFFALO RUN CREEK \\
\hline 21 & TONGUE RIVER DAM & 76 & VERONA \\
\hline 22 & SPRING GULCH & 77 & ULM \\
\hline 23 & LACEY GULCH & 78 & CLEARMONT \\
\hline 24 & STROUD CREEK & 79 & LEITER \\
\hline 25 & HAMILTON DRAW & 80 & ARVADA \\
\hline 26 & OTTER & 81 & ARVADA NE \\
\hline 27 & REANUS CONE & 82 & LAREY DRAW \\
\hline 28 & SAYLE & 83 & SPOTTED HORSE \\
\hline 29 & BLOOM CREEK & 84 & RECLUSE \\
\hline 30 & LITTLE BEAR CREEK & 85 & PITCH DRAW \\
\hline 31 & BAR V RANCH & 86 & OLIVER DRAW \\
\hline 32 & PEARL SCHOOL & 87 & STORY \\
\hline 33 & DECKER & 88 & BANNER \\
\hline 34 & HOLMES RANCH & 89 & HORSE HILL \\
\hline 35 & PINE BUTTE SCHOOL & 90 & UCROSS \\
\hline 36 & FORKS RANCH & 91 & JULIO DRAW \\
\hline 37 & QUIETUS & 92 & ARPAN BUTTE \\
\hline 38 & BEAR CREEK SCHOOL & 93 & JEWELL DRAW \\
\hline 39 & SAYLE HALL & 94 & LARIAT \\
\hline 40 & BRADSHAW CREEK & 95 & CROTON \\
\hline 41 & MOORHEAD & 96 & TRUMAN DRAW \\
\hline 42 & THREE BAR RANCH & 97 & WILDCAT \\
\hline 43 & BAY HORSE & 98 & CALF CREEK \\
\hline 44 & RANCHESTER & 99 & WESTON SW \\
\hline 45 & MONARCH & 100 & STONE MOUNTAIN \\
\hline 46 & ACME & 101 & LAKE DE SMET WEST \\
\hline 47 & BAR N DRAW & 102 & LAKE DE SMET EAST \\
\hline 48 & CEDAR CANYON & 103 & BUFFALO NE \\
\hline 49 & O T O RANCH & 104 & FREDRICK DRAW \\
\hline 50 & ROUNDUP DRAW & 105 & FLOATE DRAW \\
\hline 51 & BOX ELDER DRAW & 106 & MITCHELL DRAW \\
\hline 52 & CABIN CREEK NW & 107 & LIVINGSTON DRAW \\
\hline 53 & CABIN CREEK NE & 108 & ECHETA \\
\hline 54 & BLACK DRAW & 109 & TWENTYMILE BUTTE \\
\hline 55 & DEAD HORSE LAKE & 110 & ORIVA NW \\
\hline
\end{tabular}


Table 4. Continued.

\begin{tabular}{|c|c|c|c|}
\hline Number & 7.5-minute Quadrangle Map & Number & 7.5-minute Quadrangle Map \\
\hline 111 & RAWHIDE SCHOOL & 165 & FOURMILE RESERVOIR \\
\hline 112 & MOYER SPRINGS & 166 & SOLDIER CREEK \\
\hline 113 & NORTH RIDGE & 167 & FORT RENO \\
\hline 114 & BUFFALO & 168 & FORT RENO SE \\
\hline 115 & BUFFALO SE & 169 & NORTH BUTTE \\
\hline 116 & PINE GULCH & 170 & SAVAGETON \\
\hline 117 & BEAR DRAW & 171 & GREASEWOOD RESERVOIR \\
\hline 118 & SOMERVILLE FLATS WEST & 172 & ROCKY BUTTE GULCH \\
\hline 119 & SOMERVILLE FLATS EAST & 173 & RENO JUNCTION \\
\hline 120 & CARR DRAW & 174 & HILIGHT \\
\hline 121 & JEFFERS DRAW & 175 & OPEN A RANCH \\
\hline 122 & ORIVA & 176 & KAYCEE NE \\
\hline 123 & GILLETTE WEST & 177 & FIGURE 8 RESERVOIR \\
\hline 124 & GILLETTE EAST & 178 & SUSSEX \\
\hline 125 & FORTIN DRAW & 179 & HOUSE CREEK \\
\hline 126 & KLONDIKE RANCH & 180 & DRY FORK RANCH \\
\hline 127 & T A RANCH & 181 & ROLLING PIN RANCH \\
\hline 128 & TA RANCH NE & 182 & SOUTH BUTTE \\
\hline 129 & CRAZY WOMAN RANCH & 183 & BAKER SPRING \\
\hline 130 & PLOESSERS DRAW & 184 & RATTLESNAKE DRAW \\
\hline 131 & JUNIPER DRAW & 185 & LITTLE THUNDER RESERVOIR \\
\hline 132 & LASKIE DRAW & 186 & RENO RESERVOIR \\
\hline 133 & MORGAN DRAW & 187 & PINEY CANYON NW \\
\hline 134 & SCOTT DAM & 188 & LINCH \\
\hline 135 & FOUR BAR J RANCH & 189 & TAYLOR RANCH \\
\hline 136 & APPEL BUTTE & 190 & ARTESIAN DRAW \\
\hline 137 & THE GAP & 191 & PINE TREE \\
\hline 138 & COYOTE DRAW & 192 & TURNERCREST \\
\hline 139 & COON TRACK CREEK & 193 & RENO FLATS \\
\hline 140 & PURDY RESERVOIR & 194 & TECKLA SW \\
\hline 141 & TRABING & 195 & TECKLA \\
\hline 142 & BROWN RANCH & 196 & PINEY CANYON SW \\
\hline 143 & BOON & 197 & SAWMILL CANYON \\
\hline 144 & BOWMAN FLAT & 198 & ROSS \\
\hline 145 & NEGRO BUTTE & 199 & ROSS FLAT \\
\hline 146 & BOGIE DRAW & 200 & MACKEN DRAW \\
\hline 147 & DOUBLE TANKS & 201 & COAL DRAW NORTH \\
\hline 148 & PLEASANTDALE & 202 & BETTY RESERVOIR \\
\hline 149 & SCAPER RESERVOIR & 203 & DUGOUT CREEK NORTH \\
\hline 150 & THE GAP SW & 204 & COAL BANK DRAW \\
\hline 151 & SADDLE HORSE BUTTE & 205 & GILLAM DRAW EAST \\
\hline 152 & ANTELOPE DRAW & 206 & MARSH DRAW \\
\hline 153 & ELAINE DRAW & 207 & THOMPSON DRAW \\
\hline 154 & PROVENCE RANCH & 208 & BEAR CREEK \\
\hline 155 & HOE RANCH & 209 & COAL DRAW SOUTH \\
\hline 156 & THE NIPPLE & 210 & ALTA CREEK \\
\hline 157 & FATS DRAW & 211 & DUGOUT CREEK SOUTH \\
\hline 158 & WAGS PINNACLE & 212 & SEVEN L CREEK EAST \\
\hline 159 & PEPSSON DRAW & 213 & FLY DRAW \\
\hline 160 & THREEMILE CREEK RESERVOIR & 214 & SOUTH FORK RESERVOIR \\
\hline 161 & EAGLE ROCK & 215 & SUICIDE HILL \\
\hline 162 & NEIL BUTTE & 216 & RED HILL \\
\hline 163 & ROUGH CREEK & 217 & PATSY DRAW \\
\hline 164 & DRY CREEK RESERVOIR & 218 & BEAUCHAMP RESERVOIR \\
\hline
\end{tabular}


Table 4. Continued.

\begin{tabular}{|cl|}
\hline Number & \multicolumn{1}{c|}{ 7.5-minute Quadrangle Map } \\
\hline 219 & GUMBO HILL \\
220 & COAL HILL \\
221 & HOLDUP HOLLOW \\
222 & WHIPPLE HOLLOW \\
223 & BOBBY DRAW \\
224 & GLENROCK NW \\
225 & HYLTON RANCH \\
226 & LEUENBERGER RANCH \\
227 & GILBERT LAKE \\
\hline
\end{tabular}

Table 5. Comparison of EV coal resource calculations of the Wyodak-Anderson coal zone using 300 by $300-\mathrm{m}$ isopach versus 300 by 300-m NMT grid options, reported by coal thickness categories.

Resources are reported in millions of short tons (MST) rounded to three significant figures. Percentages are rounded to two significant figures. Columns will not sum to match the totals due to independent rounding.

\begin{tabular}{|l|c|c|c|}
\hline $\begin{array}{c}\text { Net Coal Thickness } \\
\text { Categories }\end{array}$ & $\begin{array}{c}\text { Isopach Grid Option } \\
\text { Total (MST) }\end{array}$ & $\begin{array}{c}\text { NMT Grid Option } \\
\text { Total (MST) }\end{array}$ & $\begin{array}{c}\text { Percent Difference in } \\
\text { Unrounded MST }^{1}\end{array}$ \\
\hline $2.5-5 \mathrm{ft}$ & 1,040 & 1,080 & $3.5 \%$ \\
$5-10 \mathrm{ft}$ & 6,030 & 6,380 & $5.5 \%$ \\
$10-20 \mathrm{ft}$ & 16,600 & 17,600 & $5.8 \%$ \\
$20-30 \mathrm{ft}$ & 23,100 & 23,000 & $0.78 \%$ \\
$30-40 \mathrm{ft}$ & 26,000 & 25,500 & $1.7 \%$ \\
$40-50 \mathrm{ft}$ & 34,500 & 34,400 & $0.29 \%$ \\
$50-100 \mathrm{ft}$ & 259,000 & 258,000 & $0.65 \%$ \\
$100-150 \mathrm{ft}$ & 147,000 & 147,000 & $0.23 \%$ \\
$150-200 \mathrm{ft}$ & 33,000 & 33,000 & $0.032 \%$ \\
$200-250 \mathrm{ft}$ & 3,580 & 3,580 & $0.0055 \%$ \\
$250-300 \mathrm{ft}$ & 607 & 607 & $0.00050 \%$ \\
\hline Grand Total (MST) & 551,000 & 550,000 & $0.24 \%$ \\
\hline
\end{tabular}

1. Percent difference in unrounded MST = (to calculate a positive percentage) subtracted the unrounded total of millions of short tons calculated using the NMT grid option from the unrounded total of millions of short tons calculated using the isopach grid option, divided by the unrounded total of millions of short tons using the isopach grid option, and multiplied the fraction by 100 to get a percentage representative of how much more MST were calculated using the isopach grid than using the NMT grid. 
Table 6. Comparison of coal resources for the Wyodak-Anderson coal zone calculated using EV versus ARC/INFO methods, reported by coal thickness categories. The EV method used a 300 by $300-\mathrm{m}$ isopach grid for the resource calculations. Resources are reported in millions of short tons (MST) and rounded to three significant figures. Percent is rounded to two significant figures. Resources will not sum to match the totals due to independent rounding.

\begin{tabular}{|l|c|c|c|}
\hline $\begin{array}{c}\text { Net Coal Thickness } \\
\text { Category }\end{array}$ & $\begin{array}{c}\text { Total Resource } \\
\text { Earth Vision Method } \\
\text { (MST) }\end{array}$ & $\begin{array}{c}\text { Total Resource } \\
\text { ARC Method } \\
\text { (MST) }\end{array}$ & $\begin{array}{c}\text { Percent Difference } \\
\text { in Unrounded MST }\end{array}$ \\
\hline $2.5-5 \mathrm{ft}$ & 1,040 & 960 & $7.8 \%$ \\
$5-10 \mathrm{ft}$ & 6,029 & 6,040 & $0.22 \%$ \\
$10-20 \mathrm{ft}$ & 16,600 & 17,000 & $2.6 \%$ \\
$20-30 \mathrm{ft}$ & 23,100 & 23,400 & $1.2 \%$ \\
$30-40 \mathrm{ft}$ & 26,000 & 26,000 & $0.11 \%$ \\
$40-50 \mathrm{ft}$ & 34,500 & 34,100 & $1.3 \%$ \\
$50-100 \mathrm{ft}$ & 259,000 & 261,000 & $0.78 \%$ \\
$100-150 \mathrm{ft}$ & 147,000 & 156,000 & $5.6 \%$ \\
$150-200 \mathrm{ft}$ & 33,000 & 35,000 & $5.8 \%$ \\
$200-250 \mathrm{ft}$ & 3,580 & 3,660 & $2.2 \%$ \\
$250-300 \mathrm{ft}$ & 607 & 636 & $4.7 \%$ \\
\hline Grand Total (MST) & 551,000 & 564,000 & $2.3 \%$ \\
\hline
\end{tabular}

${ }^{1 .}$ Percent difference in unrounded MST $=$ (to calculate a positive percentage) subtracted the smallest unrounded total of millions of short tons from the largest unrounded total of millions of short tons, divided by the largest unrounded total of millions of short tons, and multiplied the fraction by 100 to get a percentage representative of how much more MST were calculated using one method verses the other.

\section{CONFIDENCE LIMITS}

A confidence interval is a statistical assessment of the uncertainty associated with a point estimate. In this study, we computed 90-percent confidence intervals on the volume of coal in the Wyodak-Anderson coal zone in the measured, indicated, inferred, and hypothetical categories.

The three main potential sources of error that might bias the confidence interval are preferential sampling, measurement errors, and model fitting. The probabilistic interpretation of a confidence interval is based upon a random sample; which is not the case for the Wyodak-Anderson coal zone in the Powder River Basin, because there is preferential sampling in the areas where coal is considered to be minable. Measurement error can be caused by an error in recording coal bed thickness or defining coverage areas. Model fitting variability and bias result from the choice of models and fitting procedures.

Confidence limits for coal resources of the Wyodak-Anderson coal zone were calculated by John Schuenemeyer and Helen Power (University of Delaware), using a data set containing net coal measurements from 4,462 drill hole locations. The data set did not include data from terminated drill holes, data points with coal less than $2.5 \mathrm{ft}$ thick, or EarthVision interpretive points.

Confidence limits were derived through a complex series of steps. These steps included modeling coal thickness trends and removing the trends by using a nonparametric, regression algorithm called loess. Residual thickness was then used to compute a semivariogram and the semivariogram was fitted to an exponential model to determine measurement error. Standard deviations of coal thickness were calculated from the semivariogram model. Differences in point densities were compensated for by calculating a pseudo $\mathrm{n}$ (described in 5. below) within each reliability category and calculating the variability of volume for each of the reliability categories. Resources (in millions of short tons (MST)) were then calculated for the coal within different reliability categories at a 90-percent confidence interval 
with measurement error. Parameters used and the results of confidence limit calculations are shown in table 7.

A detailed description of the methodology is given in Schuenemeyer and Power (in press). The following steps were used for calculating the confidence limits for the Wyodak-Anderson coal zone.

1. We investigated large-scale changes in coal zone thickness and found that coal was thicker in the center of the study area. This trend was partially removed $\left(\mathrm{R}^{2}=0.49\right)$, using a nonparametric regression algorithm called loess, utilizing the Splus software program (Mathsoft Inc., 1998). The resulting residual thicknesses were used in subsequent analyses.

2. A study of spatial variation was performed using variograms and other geostatistical tools to determine and model spatial correlation. An empirical omnidirectional semivariogram was computed on residual thicknesses. This semivariogram provided information on changes in the variability of residual thicknesses as a function of distance between drill holes. Neither geometric nor zonal anisotropy was found to exist to any significant degree.

3. The semivariogram was fitted to an exponential model using a nonlinear least squares procedure. The fitted values were sill $=529.75 \mathrm{ft}$, nugget $=212.04 \mathrm{ft}$, and range $=2.357 \mathrm{ft}$. Since the measurement error appeared excessively large, an exogenously supplied value of $s_{M}=4.33 \mathrm{ft}$ was used. The choice of a value for measurement error is not critical, because only the sampling plus measurement error is reported.

4. Values of the standard deviations of thicknesses $\left(s_{h}\right)$ were obtained at $0.25,0.75$, and 3.00 miles from the exponential model described above. These corresponded to circles generated by the reliability categories of measured, indicated, and inferred respectively (Wood and others, 1983). The standard deviation values for the measured, indicated, and inferred reliability categories are $18.88 \mathrm{ft}, 23.19 \mathrm{ft}$, and $27.02 \mathrm{ft}$. The square root of the sill plus nugget effects of $26.89 \mathrm{ft}$ is used for the hypothetical category.

5. An estimate of the variability of the volume $V$ (total resource in millions of short tons (MST)) of a given reliability category, including measurement error, is $s_{C}^{2}=(k A)^{2}\left(s_{h}^{2}+\hat{\sigma}_{\varepsilon}^{2}\right) / n^{*}$, where $k$ is the coal density in short tons per acre-ft, $A$ is the area of the reliability category in meters squared, $s_{h}^{2}$ is the estimated variance of the thickness at distance $\mathrm{h}$ (taken from the semivariogram model), and $n$ * (pseudo $\mathrm{n}$ ) is the number of pseudo data points. This latter number, $n^{*}=A /\left(\pi r^{2}\right)$ with $r$ equal to the radius of the reliability category $(0.25 \mathrm{mi}, 0.75 \mathrm{mi}$, or $3.00 \mathrm{mi})$. This $n^{*}$ was computed because of the clustered nature of the drilling and the fact that the indicated and inferred categories do not contain data points. It is a conservative estimate of the minimum number of data points influencing the calculation of coal volume for the area within each reliability category. For the hypothetical category, $n^{*}=1$.

6. The $90 \%$ confidence interval estimate on $V$ for a given category is $V \pm 1.645 s_{c}$.

7. The estimate of uncertainty on the total volume $V_{T}$ was obtained by summing estimates of variance across the four reliability categories and pairwise covariation, assuming a dependence of 1.0.

The following table (table 7) shows the parameters used and the results of the confidence interval calculations for the Wyodak-Anderson coal zone at a 90 percent confidence level. Total coal resources for the Wyodak-Anderson coal zone, calculated independently and rounded to four significant figures is 550,700 million short tons. The lower and upper confidence limits at a $90 \%$ confidence interval for the Wyodak-Anderson coal are 459,300 and 642,100 million short tons respectively. 
Table 7. Wyodak-Anderson confidence limits parameters and results. Resources are reported in millions of short tons (MST) with four significant figures. Resources will not sum to match the totals for the entire area due to independent rounding.

\begin{tabular}{|c|c|c|c|c|c|}
\hline \multirow[t]{2}{*}{ Parameter } & \multicolumn{4}{|c|}{ Reliability Category } & \multirow{2}{*}{$\begin{array}{l}\text { Entire } \\
\text { Area }\end{array}$} \\
\hline & Measured & Indicated & Inferred & Hypothetical & \\
\hline Area (in meters ${ }^{2}$ ) & $1,488,759,443$ & $5,670,020,546$ & $11,140,313,431$ & $3,612,068,158$ & $21,911,161,578$ \\
\hline Percent of Area & 7 & 26 & 51 & 16 & 100 \\
\hline $\begin{array}{l}\text { Acres (=Area X } \\
.0002471)\end{array}$ & 367,880 & $1,401,092$ & $2,752,831$ & 892,561 & $5,414,365$ \\
\hline $\begin{array}{l}\text { Standard Deviation } \\
\text { (SD) (in ft, from } \\
\text { semivariogram } \\
\text { model) }\end{array}$ & 18.38 & 22.78 & 26.67 & 26.89 & \\
\hline $\begin{array}{l}\text { Acre-ft (Acres X } \\
\text { SD) }\end{array}$ & $6,759,910$ & $31,921,428$ & $73,423,804$ & $24,000,492$ & \\
\hline Volume (MST) & 43,670 & 167,700 & 303,700 & 35,610 & 550,700 \\
\hline \multicolumn{6}{|l|}{ Pseudo n } \\
\hline $\begin{array}{l}\mathrm{n}^{*}=\text { Minimum } \\
\text { Number of Points in } \\
\text { Category Area }\end{array}$ & 2,928 & 1,239 & 152 & 1 & \\
\hline $\begin{array}{c}\text { Estimates of } \\
\text { Uncertainty With }\end{array}$ & \multicolumn{4}{|c|}{ Reliability Category } & \multirow{2}{*}{$\begin{array}{c}\text { Entire } \\
\text { Area }\end{array}$} \\
\hline $\begin{array}{l}\text { Measurement Error } \\
\text { Included }\end{array}$ & Measured & Indicated & Inferred & Hypothetical & \\
\hline Volume SD (MST) & 227 & 1,634 & 10,675 & 43,028 & 55,564 \\
\hline $\begin{array}{l}\text { Half Interval Width } \\
\text { (90\% confidence } \\
\text { interval) }\end{array}$ & 374 & 2,688 & 17,560 & 70,781 & 91,403 \\
\hline $\begin{array}{l}\text { Lower } 90 \% \\
\text { Confidence Limit } \\
\text { (MST) }\end{array}$ & 43,300 & 165,000 & 286,100 & 0 & 459,300 \\
\hline $\begin{array}{l}\text { Upper } 90 \% \\
\text { Confidence Limit } \\
(\mathrm{MST})\end{array}$ & 44,050 & 170,400 & 321,200 & 106,400 & 642,100 \\
\hline $\begin{array}{l}\text { \% Error ((Half } \\
\text { interval width / } \\
\text { Volume }) * 100)\end{array}$ & 0.86 & 1.60 & 5.78 & 198.75 & 16.60 \\
\hline
\end{tabular}

(Coal density $=1,770$ short tons/acre- $\mathrm{ft}$ of subbituminous coal, $\mathrm{n}=4,462$, measurement error standard deviation $=4.33$ $\mathrm{ft}$, sill $=529.75 \mathrm{ft}^{2}$, nugget $=212.04 \mathrm{ft}^{2}$, range $=2.357 \mathrm{mi}$ (from exponential semivariogram model) $)$

\section{CONCLUSION}

Although the methods used by the USGS for calculating coal resources in different study areas vary, it appears that the methods tested here did not have a great effect on the total amount of resources calculated. According to our comparisons of calculations using different parameters and methods (tables 2 through 6), the greatest difference resulted from the use of ARC/INFO volumetrics calculations versus EarthVision calculation methods. In our study, as shown in table 5, more resources were calculated using the ARC/INFO method (2.3\% more overall, $1.8 \%$ more in Wyoming and 8.6\% more in Montana.) 
Table 5 also shows that the average coal thickness values used in the ARC/INFO method are consistently higher than the thickness values used in the EarthVision method. The ARC/INFO method assigns one value (the mean of the bounding isoline values to the entire polygon, whereas the EarthVision method uses many thickness values within each polygon. Coal resource values are ordinarily rounded to two significant figures. Upon examining the amount of short tons calculated using the two methods, we found that after rounding the resource values there was very little difference between totals derived via the two methods.

The resource calculations reported by county for different grid spacings, using the EarthVision method and the isopach grid option, were very similar (table 4). The maximum percent difference by county was $1.3 \%$ in Powder River County in Montana and Sheridan County in Wyoming. The percent difference in the resource totals for the entire area was only $0.29 \%$.

The difference in calculations using the isopach grid option versus the NMT grid option (table 2) was only $0.24 \%$ overall, with a maximum difference of $5.1 \%$ in Rosebud County, Montana. The percent difference by county was generally less than $1 \%$.

The results of our study show that although various parameters and methods may be used by different workers in the National Coal Resource Assessment nation-wide, the products resulting from these decisions show only minor differences in total resource values. The character of the data being modeled and personal preference, knowledge, and skills should determine how the resources are calculated in different areas. Because the studies differ in many ways, it is particularly important for each of the National Coal Resource studies to document the methods used, and what the resource numbers represent.

\section{SELECTED REFERENCES}

Baker, A.A., 1929, Sheridan coalfield, northward extension: U.S. Geological Survey Bulletin 806-B, p. 15-67.

Biewick, Laura R.H., Urbanowski, Shayne R., Cain, Sheila, and Neasloney, Larry, 1998, Land status and Federal mineral ownership in the Powder River Basin, Wyoming and Montana: a digital data set for geographic information systems, U.S. Geological Survey Open-File Report 98-108, coverage scale $1: 100,000$.

Boyd, Cynthia S., and Van Ploeg, Alan J., 1997, Geologic map of the Gillette 30' x 60' quadrangle, Campbell, Crook, and Weston Counties, northeastern Wyoming: Wyoming State Geological Survey Map Series 49, scale 1:100,000.

Bryson, R.P. and Bass, N.W., 1973, Geology of the Moorhead coal field, Powder River, Big Horn, and Rosebud Counties, Montana: U.S. Geological Survey Bulletin 1338, 116 p.

Bureau of Land Management, 1996, Powder River Basin Coal Production-1995; N. Braz, C. Gaskill and R. Nelson compilers, U.S. Department of the Interior, Bureau of Land Management, Casper, Wyoming, file Dldrawingslwo-map.dwg.

Culbertson, W.C., Hatch, J.R., and Affolter, R.H., 1978, Geology and coal resources of the Hanging Woman Creek Study area, Big Horn and Powder River Counties, Montana: U.S. Geological Survey Open-File Report 78-506. p. 1-37.

Daddow, P.B., 1986, Potentiametric-Surface map of the Wyodak-Anderson coal bed, Powder River Structural Basin, Wyoming, 1973-84: U.S. Department of the Interior, Water Resources Division, Water Resources Investigation Report 85-4305 (prepared in cooperation with the Bureau of Land Management).

Dunrud, C.R. and Osterwald, F.W., 1980, Effects of coal mine subsidence in the Sheridan, Wyoming area: U.S. Geological Survey Professional Paper 1164, p.7, figure 4.

Dynamic Graphics, Incorporated, 1997, EarthVision, version 4, 1015 Atlantic Ave., Alameda, CA 94501. 
Ellis, M.S., Gunther, G.L., Flores, R.M., Ochs, A.M., Stricker, G.D., Roberts, S.B., Taber, T.T., Bader, L.R., and Schuenemeyer, J.H., 1999, Preliminary report on coal resources of the WyodakAnderson coal zone, Powder River Basin, Wyoming and Montana: U.S. Geological Survey OpenFile Report 98-789A, 49 p.

Energy Information Administration (EIA), 1997, Energy Information Administration Annual Energy Outlook 1996, reference cast forecast, National Energy Modeling System run AEO96B, D101995C.

Energy Information Administration (EIA), 1998, Energy Information Administration Coal Industry Annual 1997: Department of Energy, DOE/EIA-0584 (97).

ESRI- Environmental Systems Research Institute, Inc., 1998a, ARC/INFO, version 7.1.1, 380 New York Street, Redlands, CA 92373, USA.

ESRI- Environmental Systems Research Institute, Inc., 1998b, ArcView, version.3.0a, 380 New York Street, Redlands, CA 92373, USA.

Flores, R.M., 1986, Styles of coal deposition in Tertiary alluvial deposits, Powder River Basin, Montana and Wyoming: Geological Society of America Special Paper 210, p. 79-102.

GRG Corporation, 1996, StratiFact, relational database software, version 4.5: GRG Corporation, 4175 Harlan Street, Wheatridge, CO 80033-5150.

Heffern, Edward L., Coates, Donald A., Whiteman, Jason, and Ellis, Margaret S., 1993, Geologic map showing distribution of clinker in the Tertiary Fort Union and Wasatch Formations, Northern Powder River Basin, Montana, U.S. Geological Survey Coal Investigations Map C-142, scale $1: 175,000$.

Kanizay, S.P., 1978, Preliminary geologic map of the Sheridan area, northwestern Powder River Basin, Wyoming, U.S. Geological Survey Miscellaneous Field Studies Map MF-1043, scale 1:50,000.

Kennecott Energy and Peter Kiewit and Sons, unknown, Maps showing lease boundaries, extent of mining, and areas planned for future mining in the Decker Coal Mine: scales 1:48,000 and $1: 24,000$.

Kent, B.H., and Berlage, L.J., 1980, Geologic map of the Recluse 1 x 2 degree quadrangle, Campbell and Crook Counties, Wyoming: U.S. Geological Survey Coal Investigations Map C-81-D, scale $1: 100,000$.

Love, J.D., and Christiansen, A.C., 1985, Geologic map of Wyoming: U.S. Geological Survey, scale $1: 500,000$.

Mathsoft Inc., 1998, S-PLUS, statistics software program, Professional release 2, version 4.5: Mathsoft, Inc., 101 Main Street, Cambridge, MA 02142-1521.

Roberts, L.N.R., Mercier, T.J., Biewick, L.R.H., and Blake, Dorsey, 1998, A procedure for producing maps and resource tables of coals assessed during the U.S. Geological Survey's National Coal Assessment: Fifteenth Annual International Pittsburgh Coal Conference Proceedings, CD-ROM (ISBN 1-890977-15-2), 4 p.

Roberts, L.N.R., and Biewick, L.R.H., in press, Calculation of coal resources using ARC/INFO and EarthVision: Methodology for the National Coal Resource Assessment: U.S. Geological Survey Open-File Report, 9 p.

Robinson, L.N. and Culbertson, W.C., 1984, Map showing isopachs of coal and overburden of the Canyon coal bed, Birney 30'x 60' quadrangle, Big Horn and Rosebud Counties, Montana: U.S. Geological Survey Coal Investigations Map C-96-B, scale 1:100,000.

Ross, C.P., Andrews, D.A., and Witkind, I.J., 1955, Geologic map of Montana: U.S. Geological Survey and Montana Bureau of Mines and Geology, scale 1:500,000.

Schuenemeyer, J. H. and Power H., in press, Uncertainty estimation for resource assessment-An application to coal: Mathematical Geology.

Tewalt, S.J., 1998, National coal resource assessment methodology: Comparison of resource calculation methods by two geographic information systems (GIS): U.S. Geological Survey Open-File Report 98-365, 5 p.

U.S. Geological Survey Global Land Information System-GLIS, 1997, digital spatial data obtained from http://edcwww.cr.usgs.gov/glis/glis.html. 
Warren, W.C., 1959, Reconnaissance geology of the Birney-Broadus coal field, Rosebud and Powder River Counties, Montana: U.S. Geological Survey Bulletin 1072-J, p. 561-585.

Wood, Gordon H. Jr., Kehn, Thomas M., Carter, M. Devereux, and Culbertson, William C., 1983, Coal resource classification system of the U.S. Geological Survey: U.S. Geological Survey Circular $891,65 \mathrm{p}$.

\section{APPENDIX}

The following EV grid reports show all thickness values in feet and all $\mathrm{x}$ values, $\mathrm{y}$ values, and grid spacings in meters. Items of particular interest for selecting the appropriate grid for use in our study are shown in bold type. The negative coal thickness values shown in the isopach grid reports indicate that there was information used from drill holes that terminated before the entire Wyodak-Anderson coal zone interval was penetrated. Negative thickness is treated as a "greater than" value in the EV isopach gridding option.

\section{Default Grid Spacing (3,520 x 3,606 m) Isopach Grid:}

Net coal thickness mean value: 47.79927

Standard deviation of Net coal thickness: 54.63241

Number of data points:

5414

Number of points outside of study boundary: 0

Number of null data points: $\quad 0$

Number of invalid points:

0

Number of points with comments attached: 54

Number of faults:

0

Number of points used as multiple data points: 2139

Number of points used for grid:

3206

Range of X values:

$-91438.23 \quad 68419.46$

Range of Y values:

50535885340636

Range of net coal thickness values: $\quad-169284$

Range of grid X values: $\quad-145000140525$

Range of grid Y values: $\quad 50200005464276$

Range of grid net coal thickness values:

Mean net coal thickness value in grid: $\quad 16.17833$

Standard deviation of net coal thickness value in grid:

249.5273

Number of null nodes in grid:

0

Average absolute $Z$ error of net coal thickness: 12.24746 (3.446739\%)

Standard deviation of $Z$ error (net coal thickness):

14.14046

Maximum $\mathrm{Z}$ error:

$113.1543(31.84442 \%)$

Maximum error of $\mathrm{X}, \mathrm{Y}$, and $\mathrm{Z}$ values:

175.7812519185251

\section{Default Grid Spacing (3,520 X 3,606 m) NMT Grid:}

Net coal thickness mean value:

62.81982

Standard deviation of Net coal thickness: 41.69276

Number of data points:

4622

Number of points outside of study boundary: 0

Number of null data points:

Number of invalid points:

0

Number of points with comments attached: 72

Number of faults:

0

Number of points used as multiple data points: 1952 
Number of points used for grid:

Range of $X$ values:

2670

Range of Y values:

$-91438.23 \quad 68419.46$

50535885340636

Range of net coal thickness values:

Range of grid X values:

$0 \quad 284$

Range of grid Y values:

$-145000140525$

50200005464276

Range of grid net coal thickness values:

1

249.5275

Mean net coal thickness value in grid:

16.70028

Standard deviation of net coal thickness value in grid:

Number of null nodes in grid:

0

Average absolute $\mathrm{Z}$ error of net coal thickness: 11.98783

Standard deviation of $Z$ error (net coal thickness):

28.86244

Maximum Z error:

$113.1543 \quad(31.04782 \%)$

Maximum error of $\mathrm{X}, \mathrm{Y}$, and $\mathrm{Z}$ values: $\quad 175.7812519185251$

Many of the data points in the Powder River Basin are very closely spaced. The default grid spacing of 3,520 by 3,606 meters was so large that many of the data points were not used in creating the grids. With the default grid spacing, 3,206 out of 5,414 (59\%) points were used for the isopach grid, and 2,670 out of 4,622 (58\%) data points were used for the NMT grid. The average absolute $\mathrm{z}$ error was relatively high, about $3.4 \%$ for the isopach gridding and $3.3 \%$ for the NMT gridding. The isopach grid and the NMT grid isopach maps look very similar in their general configuration. Both isopach maps contain contours that appear to lack detail. The isopach gridding option used more data points to create the grid. Because the grids produced applying the default grid spacing used only about 50 percent of the data points, these grids were considered unacceptable. An isopach map created using the default grid spacing is shown in map A. on figure 4.

\section{1,000 x 1,000-m Grid Spacing Isopach Grid:}

Net coal thickness mean value: $\quad 47.79927$

Standard deviation of Net coal thickness: 54.63241

Number of data points: $\quad \mathbf{5 4 1 4}$

Number of points outside of study boundary: 0

Number of null data points: $\quad 0$

Number of invalid points:

0

Number of points with comments attached: 54

Number of faults:

0

Number of points used as multiple data points: 397

Number of points used for grid:

4948

Range of X values: $\quad-91438.23 \quad 68419.46$

Range of Y values: $\quad 50552615340636$

Range of net coal thickness values: $\quad-169284$

Range of grid X values: $\quad-145000137000$

Range of grid Y values: $\quad 50200005461000$

Range of grid net coal thickness values: $\quad 1 \quad 273.6533$

Mean net coal thickness value in grid: $\quad 16.76521$

Standard deviation of net coal thickness value in grid: $\quad 29.0988$

Number of null nodes in grid:

0

Average absolute $Z$ error of net coal thickness: $6.074759 \quad \mathbf{( 1 . 2 7 7 4 1 5 \% )}$

Standard deviation of $Z$ error (net coal thickness):

Maximum Z error: $\quad 110.1821 \quad$ (23.16936\%)

Maximum error of X, Y, and Z values: $\quad 38742.175218148195 .1$ 


\section{1,000 x 1,000-m Grid Spacing Normal Minimal Tension Grid:}

Net coal thickness mean value: $\quad 62.81982$

Standard deviation of Net coal thickness: 41.69276

Number of data points: $\quad \mathbf{4 6 2 2}$

Number of points outside of study boundary: $\quad 0$

Number of null data points: $\quad 0$

Number of invalid points: $\quad 0$

Number of points with comments attached: 72

Number of faults:

0

Number of points used as multiple data points: 354

Number of points used for grid:

4268

Range of $X$ values:

$-91438.23 \quad 68419.46$

Range of Y values:

50535885340636

Range of net coal thickness values: $\quad 0 \quad 284$

Range of grid X values: $\quad-145000138000$

Range of grid Y values: $\quad 50200005462000$

Range of grid net coal thickness values: $\quad 1 \quad 273.6533$

Mean net coal thickness value in grid: $\quad 17.49016$

Standard deviation of net coal thickness value in grid: $\quad 29.19929$

Number of null nodes in grid: 0

Average absolute $Z$ error of net coal thickness: $5.730798 \quad$ (1.242115\%)

Standard deviation of $Z$ error (net coal thickness): $\quad 9.842724$

Maximum Z error: 114.4404 (24.80426\%)

Maximum error of X, Y, and Z values: $\quad 40488.4752185090$

The 1,000 by $1,000-\mathrm{m}$ grid spacing was still relatively coarse, and although it used more points than the default grid spacing, it still used only 4,948 out of 5,414 (91\%) data points for the isopach grid and 4,268 out of 4,622 (92\%) points for the NMT grid. The average absolute $\mathrm{z}$ error of $1.3 \%$ for the isopach grid, and $1.2 \%$ for the NMT grid, was less than half of the average z error produced using both of the grid options and the default grid spacing,

The isopach grid and NMT grid isopach maps looked very similar and both honored just over $90 \%$ of the data. Although the grids produced using the 1,000 by $1,000-\mathrm{m}$ grid were more accurate than those produced using the default grid spacing, we determined that a higher level of accuracy was preferable. Smaller grid sizes were therefore tested.

\section{0 x 800-m Grid Spacing Isopach Grid:}

Net coal thickness mean value:

47.79927

Standard deviation of Net coal thickness: 54.63241

Number of data points:

5414

Number of points outside of study boundary: 0

Number of null data points: $\quad 0$

Number of invalid points:

0

Number of points with comments attached: 54

Number of faults:

0

Number of points used as multiple data points: 233

Number of points used for grid:

5112

Range of $X$ values:

$-91438.23 \quad 68419.46$

Range of Y values: $\quad 50535885340636$

Range of net coal thickness values: $\quad-169 \quad 284$ 


\author{
Range of grid X values: $\quad-145000137400$ \\ Range of grid Y values: $\quad 50200005461600$ \\ Range of grid net coal thickness values: $\quad 1 \quad 280.7725$ \\ Mean net coal thickness value in grid: $\quad 21.59612$ \\ Standard deviation of net coal thickness value in grid: $\quad 31.2261$ \\ Number of null nodes in grid: $\quad 0$ \\ Average absolute $Z$ error of net coal thickness: $5.258592 \quad$ (1.061217\%) \\ Standard deviation of $Z$ error (net coal thickness): $\quad 9.294349$ \\ Maximum Z error: $\quad 98.57388 \quad$ (19.89284\%) \\ Maximum error of X, Y, and Z values: $\quad 41957.8452188203 .3$
}

\title{
800 x 800-m Grid Spacing NMT Grid:
}

Net coal thickness mean value: $\quad 62.81982$

Standard deviation of Net coal thickness: 41.69276

Number of data points: $\quad \mathbf{4 6 2 2}$

Number of points outside of study boundary: 0

Number of null data points: $\quad 0$

Number of invalid points: $\quad 0$

Number of points with comments attached: 72

Number of faults: $\quad 0$

Number of points used as multiple data points: 207

Number of points used for grid:

4415

Range of X values: $\quad-91438.23 \quad 68419.46$

Range of Y values: $\quad 50535885340636$

Range of net coal thickness values: $\quad 0 \quad 284$

Range of grid X values: $\quad-145000137400$

Range of grid Y values: $\quad 50200005461600$

Range of grid net coal thickness values: $\quad 1 \quad 280.7725$

Mean net coal thickness value in grid: $\quad 21.88455$

Standard deviation of net coal thickness value in grid: $\quad 31.35258$

Number of null nodes in grid: $\quad 0$

Average absolute $Z$ error of net coal thickness: $4.937365 \quad \mathbf{( 1 . 0 3 0 3 5 3 \% )}$

Standard deviation of Z error (net coal thickness): $\quad 9.09726$

Maximum Z error: $\quad 96.8564(20.21246 \%)$

Maximum error of X, Y, and Z values: $\quad 46637.775217112142$

We created new grids with grid spacings of 800 by $800 \mathrm{~m}$. These grids used more data points than the previous grids. The isopach grid used 5,112 out of 5,414 (94\%) data points and the NMT grid used 4,415 out of 4,622 (96\%) data points. The average absolute grid error was $1.1 \%$ for the isopach grid and $1.0 \%$ for the NMT grid. The isopach grid and the NMT grid isopach maps look very similar in their general configuration. The average absolute $\mathrm{z}$ error was slightly higher for the isopach grid, and although it used 697 more data points than the NMT grid, it used a smaller percentage of data points to produce the final grid. Because over 200 data points were still not being used to create these grids, we continued to test grids with smaller grid spacings. 
500 x 500-m Grid Spacing Isopach Grid:

Net coal thickness mean value: $\quad 47.79927$

Standard deviation of Net coal thickness: 54.63241

Number of data points:

5414

Number of points outside of study boundary: $\quad 0$

Number of null data points: $\quad 0$

Number of invalid points: $\quad 0$

Number of points with comments attached: 54

Number of faults:

0

Number of points used as multiple data points: 86

Number of points used for grid:

Range of $X$ values:

5259

Range of Y values:

$-91438.23 \quad 68419.46$

Range of net coal thickness values: $\quad-169284$

Range of grid X values: $\quad-145000137000$

Range of grid Y values: $\quad 50200005461000$

Range of grid net coal thickness values: $\quad 1 \quad 274.9012$

Mean net coal thickness value in grid: $\quad 17.15658$

Standard deviation of net coal thickness value in grid: $\quad 29.54831$

Number of null nodes in grid: 0

Average absolute $Z$ error of net coal thickness: $3.613605 \quad \mathbf{( 0 . 7 4 9 2 2 4 7 \% )}$

Standard deviation of $Z$ error (net coal thickness): $\quad 7.461863$

Maximum Z error: $\quad 99.39446 \quad$ (20.6079\%)

Maximum error of X, Y, and Z values: 40368.985218378132 .6

\section{0 x 500-m Grid Spacing NMT Grid:}

Net coal thickness mean value: $\quad 62.81982$

Standard deviation of Net coal thickness: 41.69276

Number of data points: $\quad \mathbf{4 6 2 2}$

Number of points outside of study boundary: 0

Number of null data points: $\quad 0$

Number of invalid points: $\quad 0$

Number of points with comments attached: 72

Number of faults:

0

Number of points used as multiple data points: 60

Number of points used for grid:

4562

Range of X values:

Range of Y values:

$-91438.23 \quad 68419.46$

50535885340636

Range of net coal thickness values: $\quad 0 \quad 284$

Range of grid X values: $\quad-145000137000$

Range of grid Y values: $\quad 50200005461000$

Range of grid net coal thickness values: $\quad 1 \quad 274.9018$

Mean net coal thickness value in grid: $\quad 17.94645$

Standard deviation of net coal thickness value in grid: $\quad 29.6714$

Number of null nodes in grid:

0

Average absolute $Z$ error of net coal thickness: $3.313015 \quad(\mathbf{0 . 7 0 5 3 5 2 5 \% )}$

Standard deviation of $Z$ error (net coal thickness): $\quad 6.931679$

Maximum Z error: $\quad 84.64108 \quad(18.02038 \%)$

Maximum error of X, Y, and Z values: $\quad 41957.8452188203 .3$ 
The grids produced with the 500 by 500 -m grid spacing used many more data points than the grids produced with coarser grid spacings. The 500 by 500 -m grids used 5,259 out of 5,414 (97\%) data points using the isopach grid option and 4,562 out of 4,622 (99\%) data points using the NMT grid option. Many of the data points in the Powder River Basin are very closely spaced, especially in the areas of active mining. The average absolute $\mathrm{z}$ error was $0.7 \%$ for the grids produced using both grid options. This is considerably less $\mathrm{z}$ error than in the previous grids tested. The isopach grid and the NMT grid isopach maps look very similar in their general configuration. It was decided that the level of detail using this grid spacing was acceptable for use in making the polygons for the net coal isopach coverage in ARC/INFO.

In testing the grids with 500 by 500-m grid spacing, we found that although the net coal thickness polygon coverages created using both grid options were satisfactory; we had problems using the 500 by $500-\mathrm{m}$ grid when calculating volumetrics in the EarthVision program. As explained previously, in order to calculate volumetrics in EarthVision there must be at least one grid node within a polygon. The 500 by $500-\mathrm{m}$ grid was not fine enough to meet this criteria. We therefore tested smaller grids using 300 by $300-\mathrm{m}$ grid spacing.

300 x 300-m Grid Spacing Isopach Grid:

Net coal thickness mean value: 47.79927

Standard deviation of Net coal thickness: 54.63241

Number of data points:

5414

Number of points outside of study boundary: 0

Number of null data points: $\quad 0$

Number of invalid points:

0

Number of points with comments attached: 54

Number of faults: $\quad 0$

Number of points used as multiple data points: 21

Number of points used for grid:

5324

Range of X values:

Range of Y values:

$-91438.23 \quad 68419.46$

Range of net coal thickness values: $\quad-169284$

Range of grid X values: $\quad-145000137000$

Range of grid Y values: $\quad 50200005460700$

Range of grid net coal thickness values: $\quad 1 \quad 285$

Mean net coal thickness value in grid: $\quad 18.5292$

Standard deviation of net coal thickness value in grid: $\quad 29.25462$

Number of null nodes in grid:

0

Average absolute $Z$ error of net coal thickness: $2.302457 \quad(\mathbf{0 . 4 7 2 8 8 6 5 \% )}$

Standard deviation of $Z$ error (net coal thickness):

Maximum Z error: $\quad 98.81242 \quad$ (20.29061\%)

Maximum error of X, Y, and Z values: $\quad 41199.5352190405$

\section{0 x 300-m Grid Spacing NMT Grid:}

Net coal thickness mean value:

Standard deviation of Net coal thickness: 41.69276

Number of data points: $\quad \mathbf{4 6 2 2}$

Number of points outside of study boundary: 0

Number of null data points: $\quad 0$

Number of invalid points: $\quad 0$

Number of points with comments attached: 72

Number of faults: 
Number of points used as multiple data points: 7

Number of points used for grid:

4,615

Range of $X$ values:

$-91,438.23 \quad 68,419.46$

Range of Y values: $\quad 5,053,588 \quad 5,340,636$

Range of net coal thickness values: $\quad 0 \quad 284$

Range of grid X values: $\quad-145,000137,000$

Range of grid Y values: $\quad 5,020,000 \quad 5,460700$

Range of grid net coal thickness values: $\quad 1 \quad 285$

Mean net coal thickness value in grid: $\quad 22.02523$

Standard deviation of net coal thickness value in grid: 29.49223

Number of null nodes in grid:

0

Average absolute $Z$ error of net coal thickness: $2.12727 \quad(\mathbf{0 . 4 4 2 0 9 4 3 \% )}$

Standard deviation of $Z$ error (net coal thickness):

5.544803

Maximum Z error: $\quad 98.7226$ (20.51677\%)

Maximum error of X, Y, and Z values: $\quad 41,199.53 \quad 5,219,040 \quad 5$

The 300 by 300-m isopach and NMT grids both honored over $98 \%$ of the data points, using 5,324 out of 5,414 (98\%) data points for the isopach grid and 4,615 out of 4,622 (99.8\%) data points for the NMT grid. The average absolute grid error was .5\% for the isopach grid and $.4 \%$ for the NMT grid. The isopach grid and NMT grid isopach maps looked very similar in their general configuration and did not differ significantly from the isopach maps created using the 500 by $500-\mathrm{m}$ grid spacings. Because the 300 by $300-\mathrm{m}$ grid contained more data points it was used for the coal resource calculations in EV. 